See discussions, stats, and author profiles for this publication at: https://www.researchgate.net/publication/304995302

\title{
Accountability in the EU Data Protection Reform: Balancing Citizens' and Business' Rights
}

Chapter · July 2016

DOI: 10.1007/978-3-319-41763-9_11

\section{CITATIONS}

0

2 authors:

Lina Jasmontaite

Vrije Universiteit Brussel

21 PUBLICATIONS 61 CITATIONS

SEE PROFILE
Valerie Verdoodt

The London School of Economics and Political Science

34 PUBLICATIONS 160 CITATIONS

SEE PROFILE

Some of the authors of this publication are also working on these related projects:

Project AdLit Project View project

Project IT Ethics View project 
a 8

1

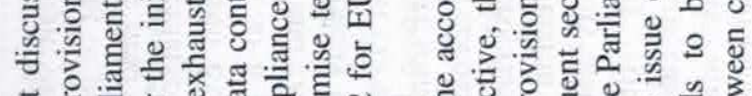

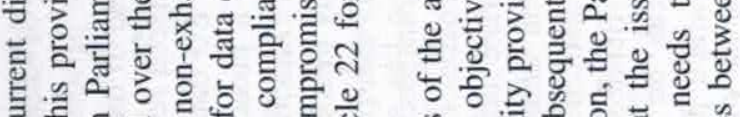

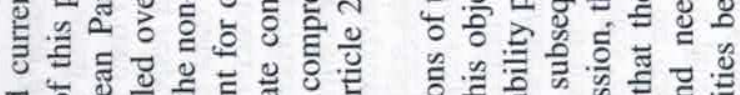

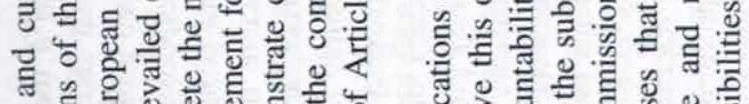

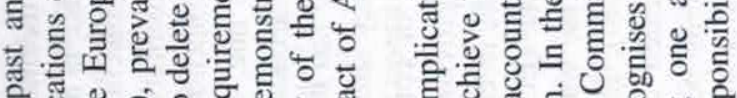
1. a

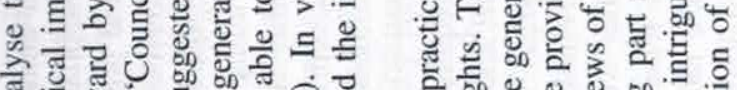

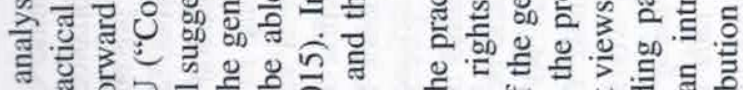
$\Omega$ ส

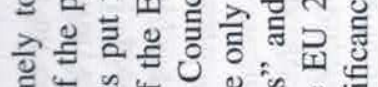

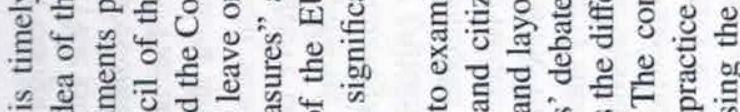

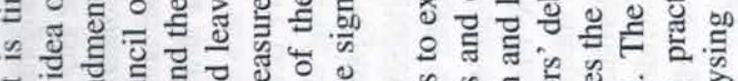

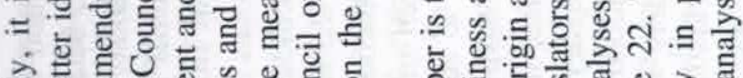

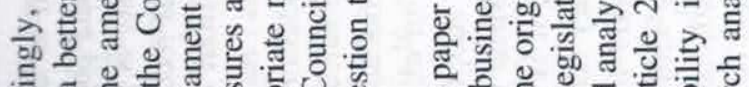

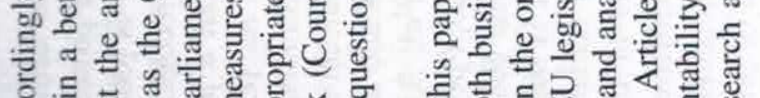

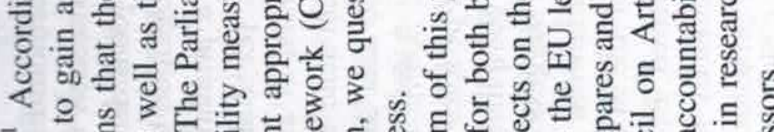

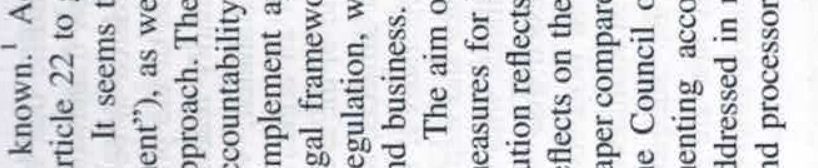

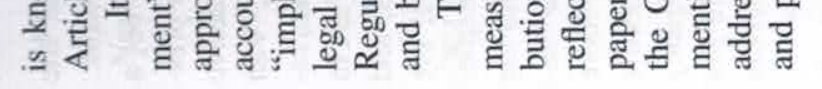

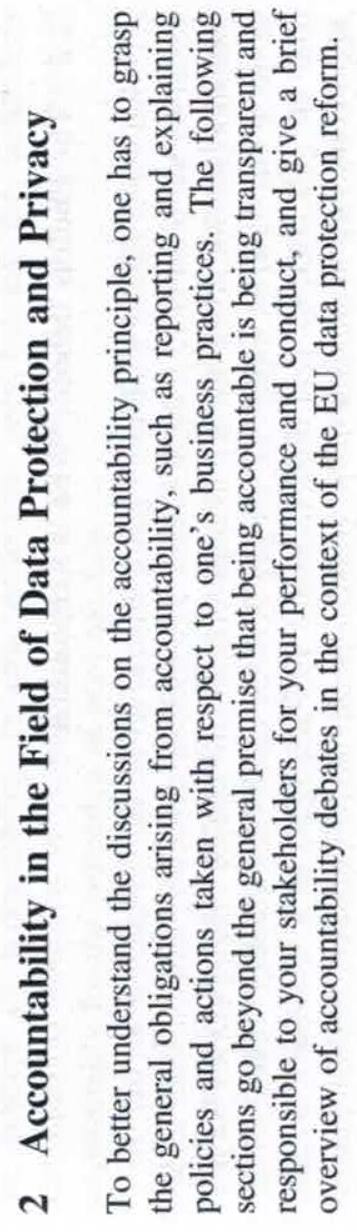

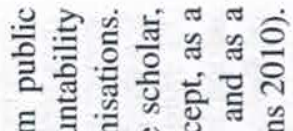

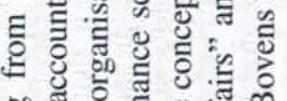

沵

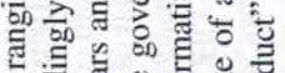

현

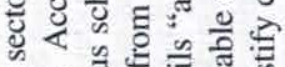

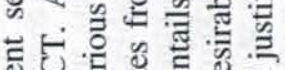

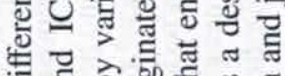

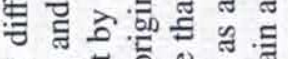

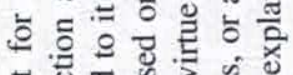

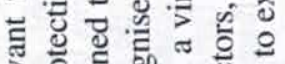

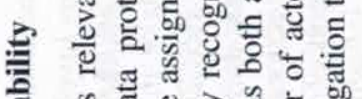

$\therefore$ 牙

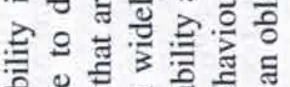

프

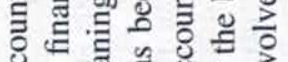

를 छ

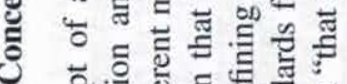

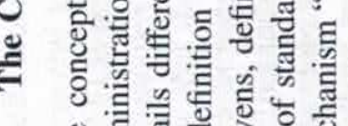

సี

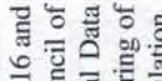

สิ

跣鸟

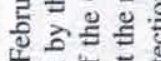

$\Xi$ 它 플

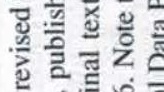

늘

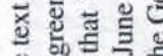

둘

棺解

㱐

ब

z...

政

远安

준유.

萦 9

造

ᄃ은

范

ठ․․

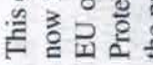

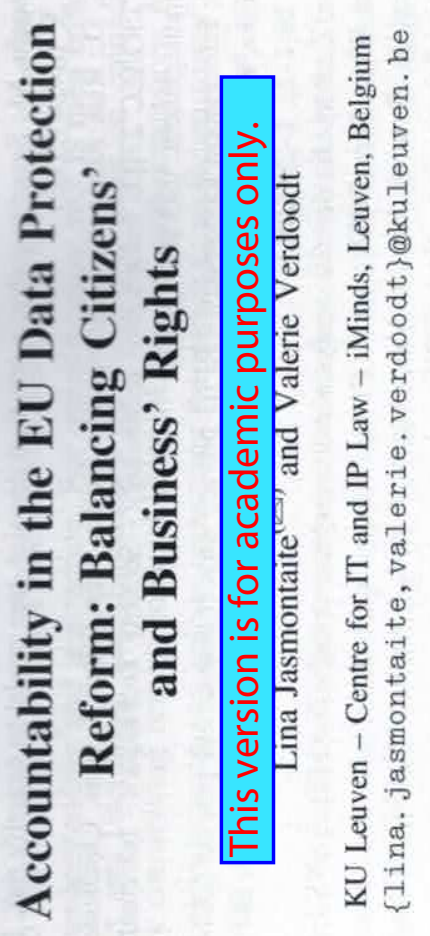

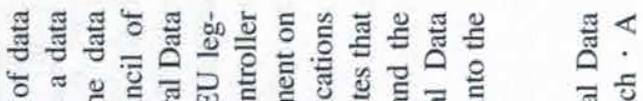

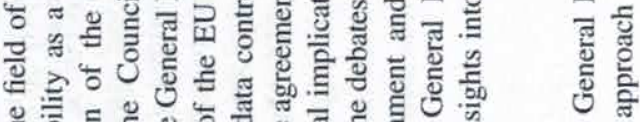

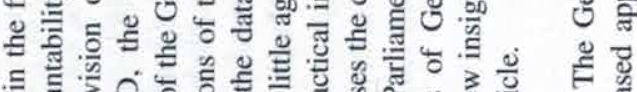

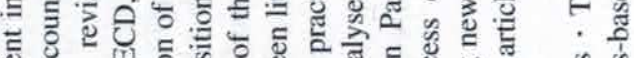

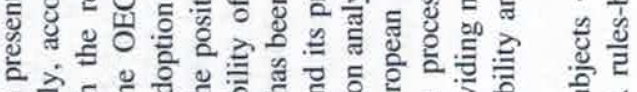

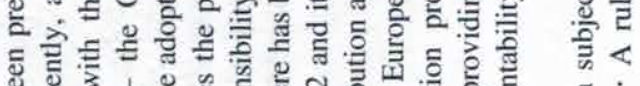

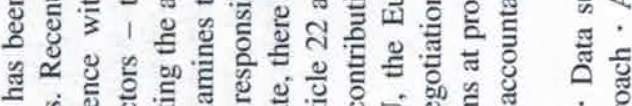

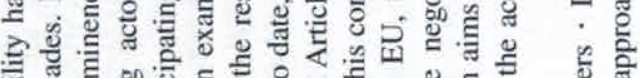

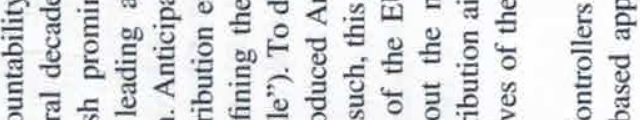

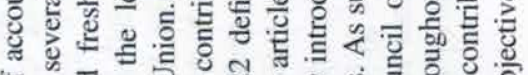

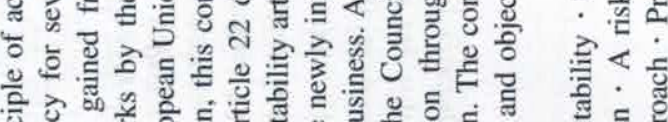

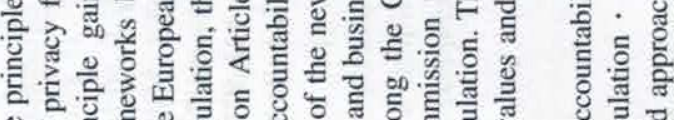

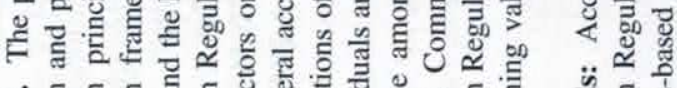

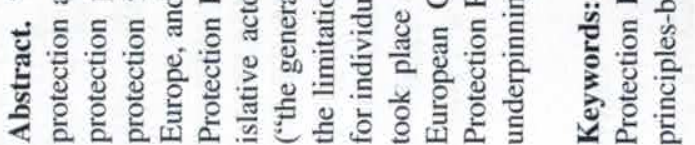

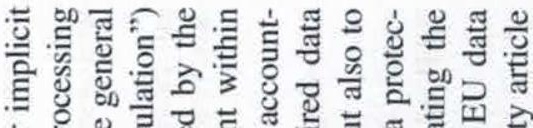
.

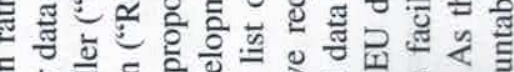

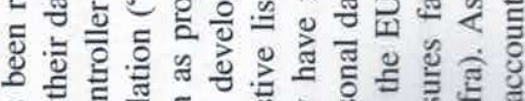

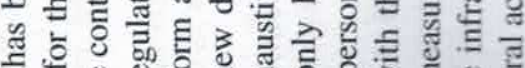

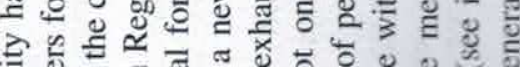

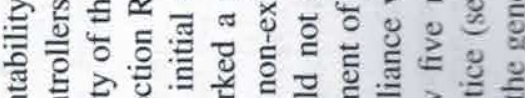

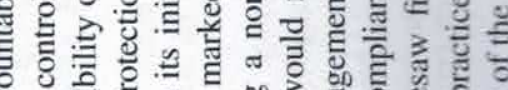

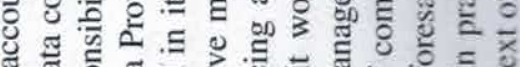

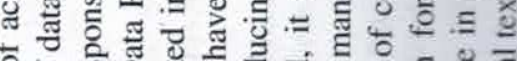

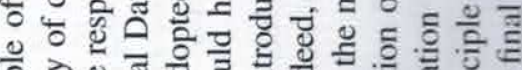

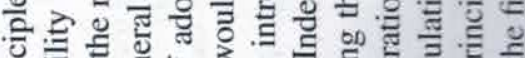
政:

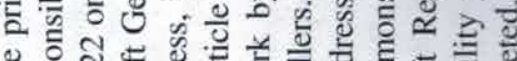
巳 б

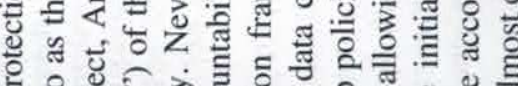

5

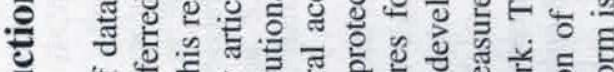

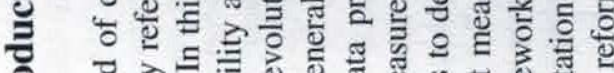
는 즘 


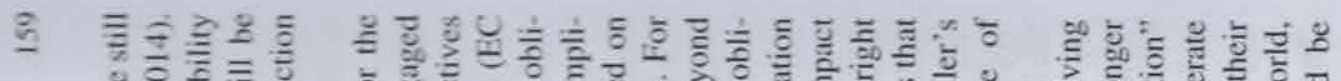

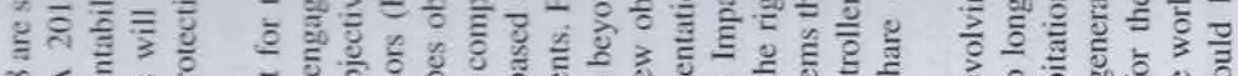

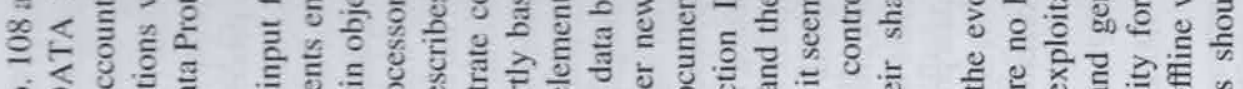

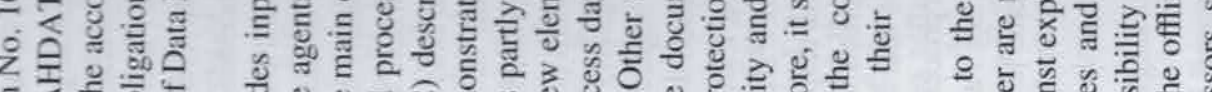

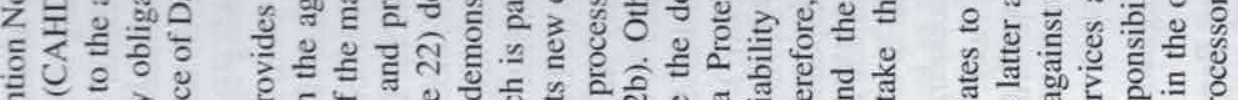
ए 플

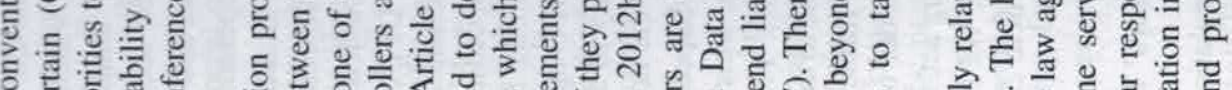

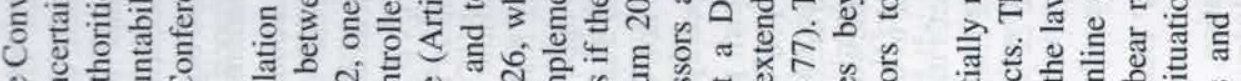

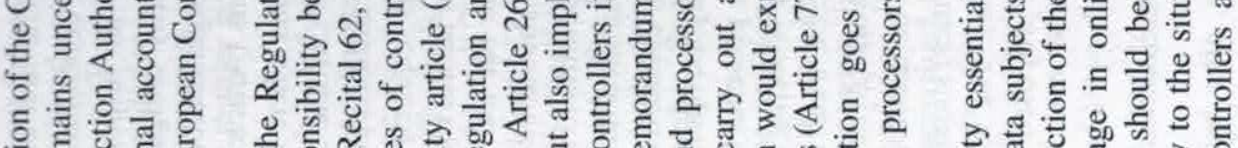

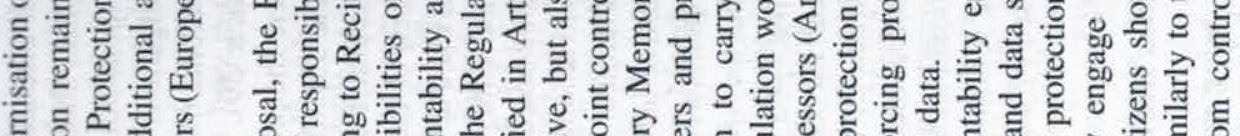

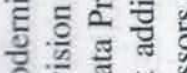
है

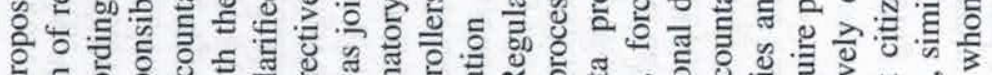
ฮ :

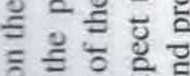

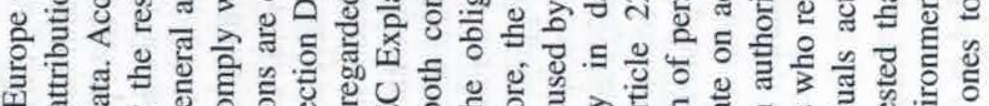

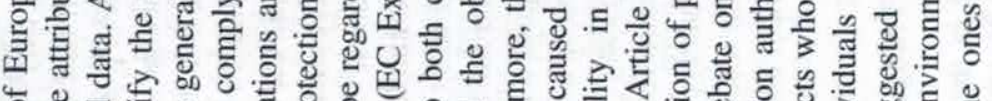

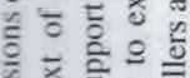

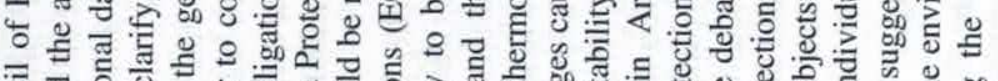
य के

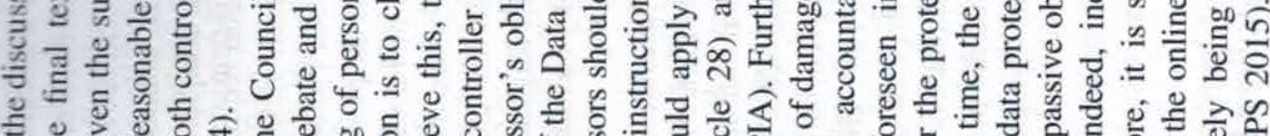

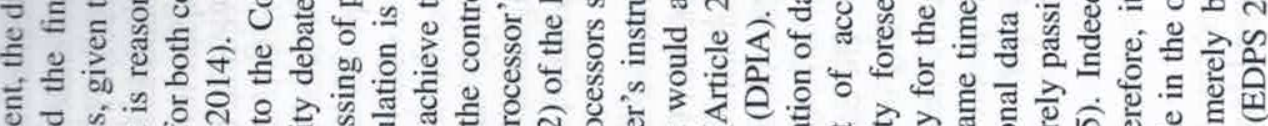

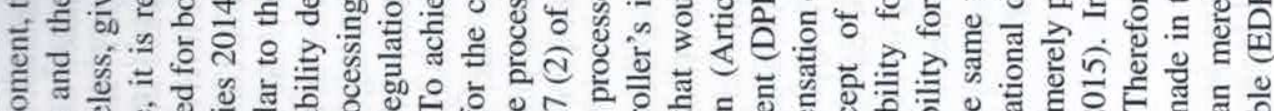
品

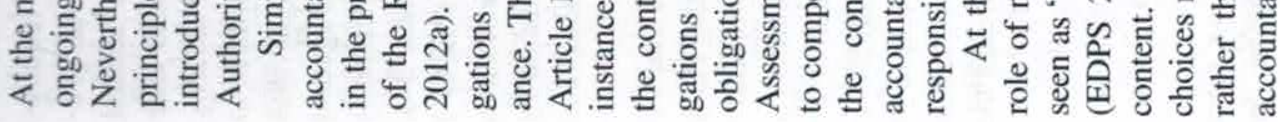

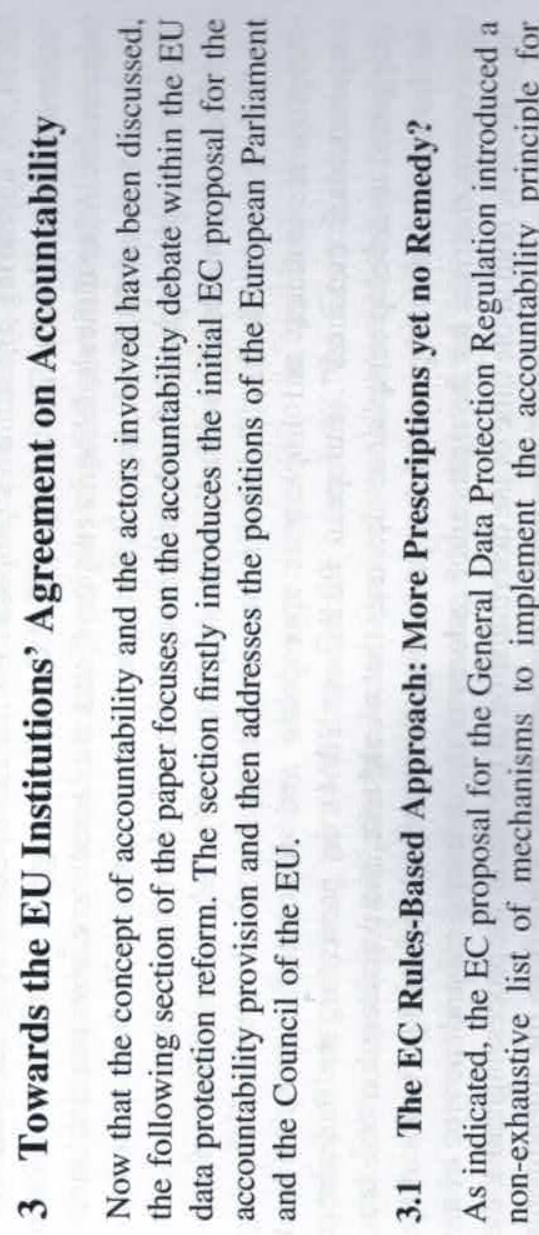

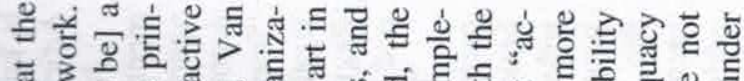

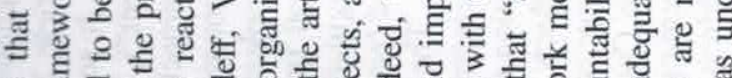

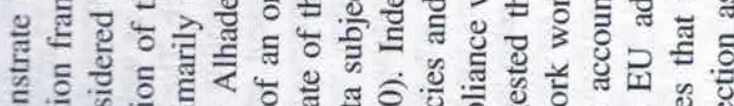

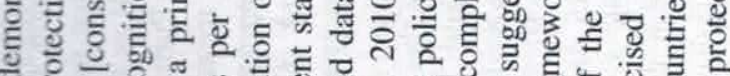

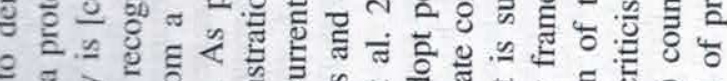

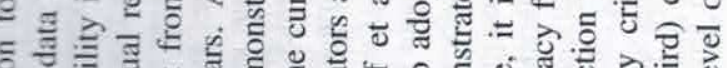
等

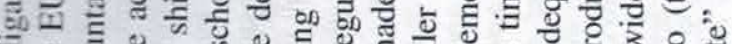

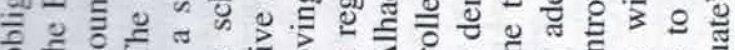
일

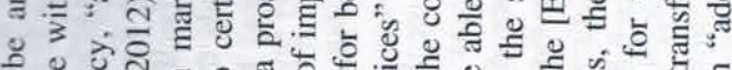

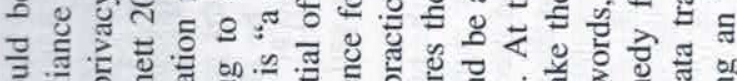

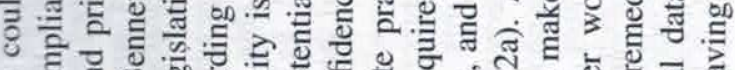

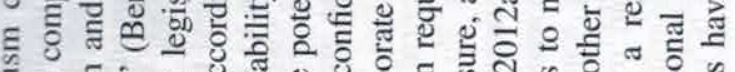

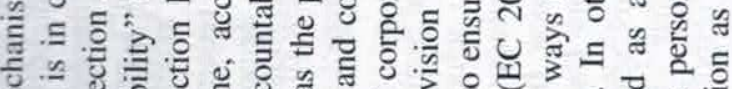

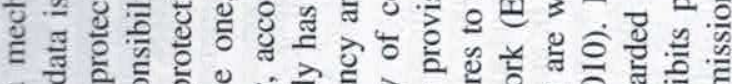

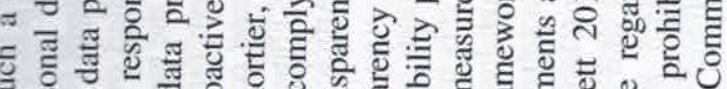

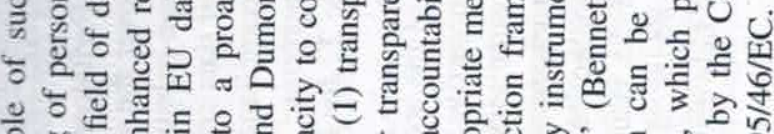

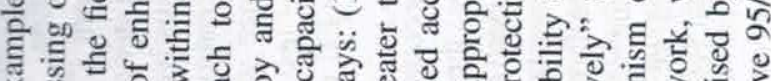
6.

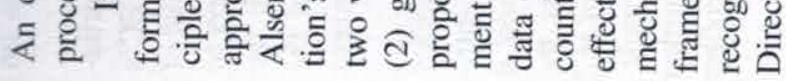

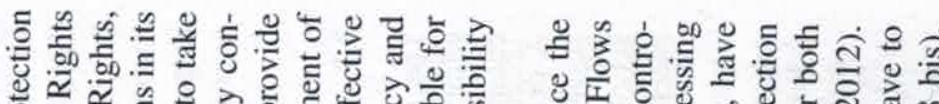
뜬

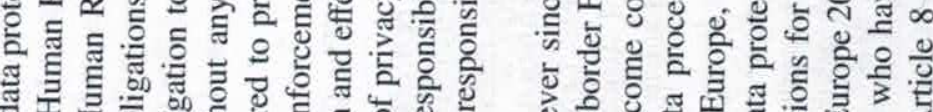

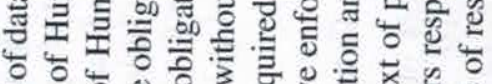

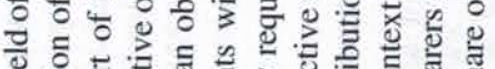
等

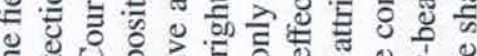

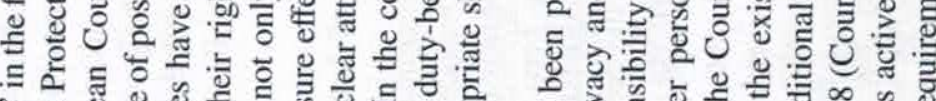
等

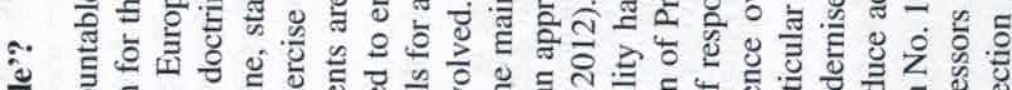
等

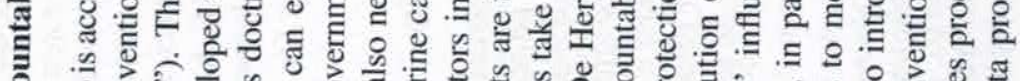

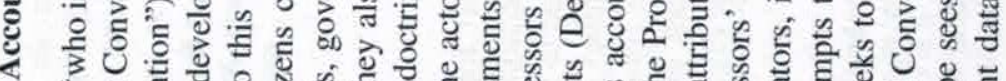

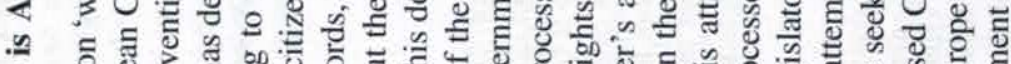

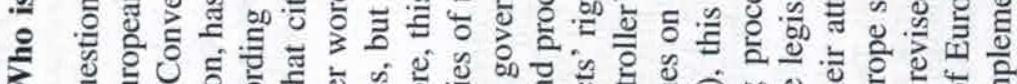
等

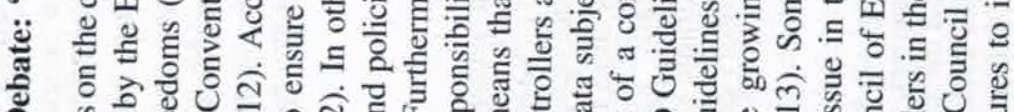

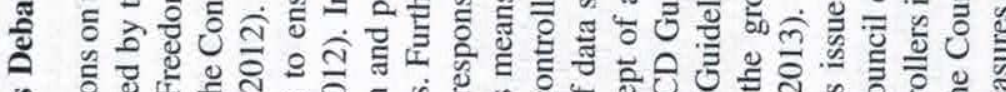

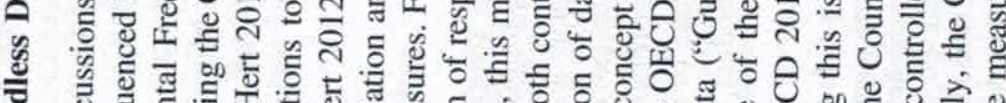

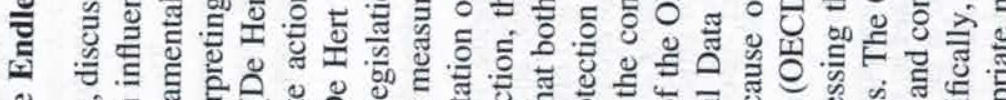
Eั

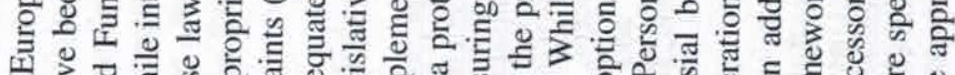

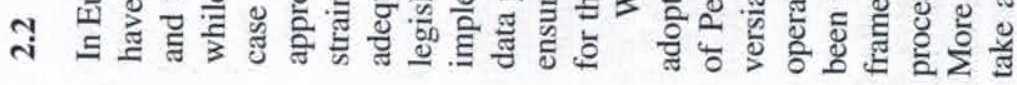




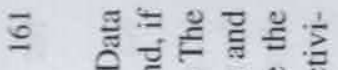
踠

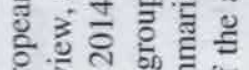
武 引

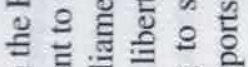

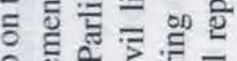

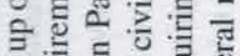
उ छ ॠ

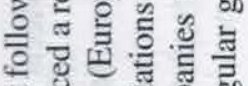

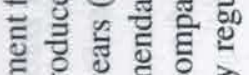
氙

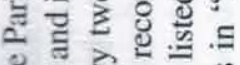

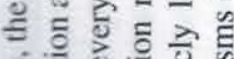

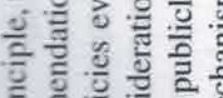

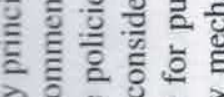

욜을

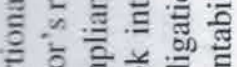

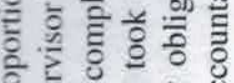

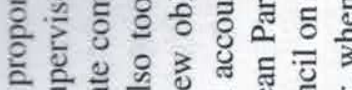

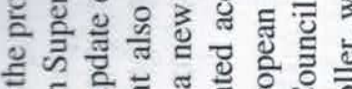

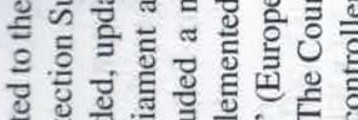

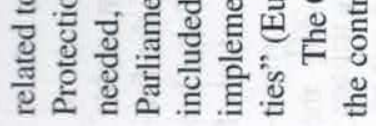

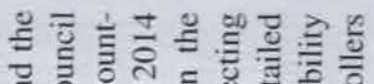

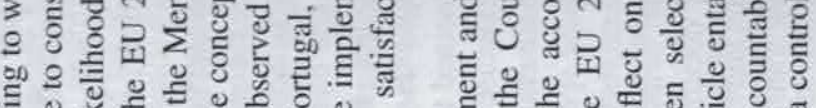

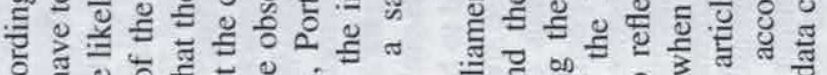

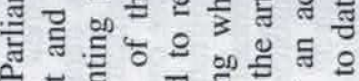

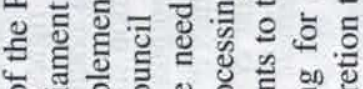

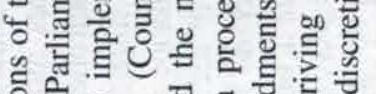

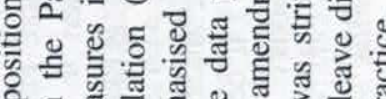
है ह

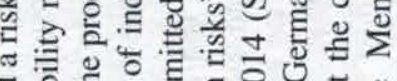
๓

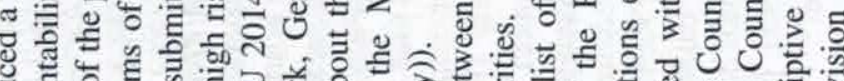
范药 ठ \&

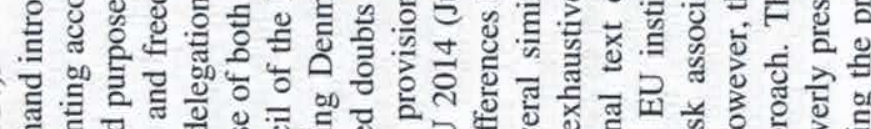

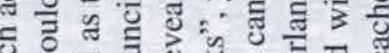
$3 \overline{0} 0$ ऐ है ป气

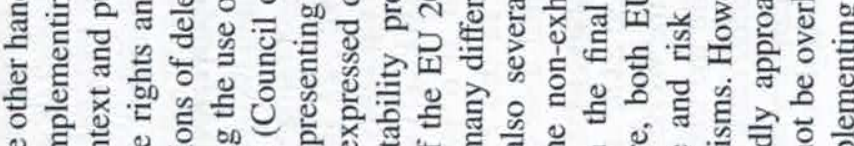

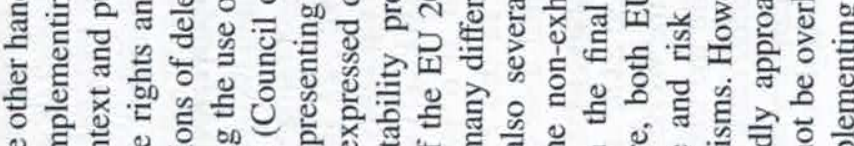

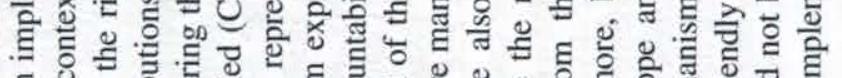


MIn⿴囗十)

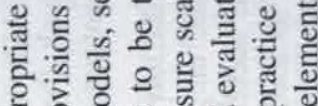

ㅇํㄹ

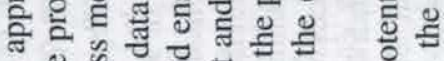

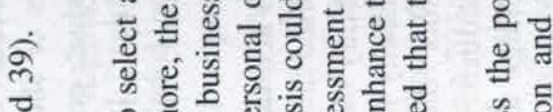

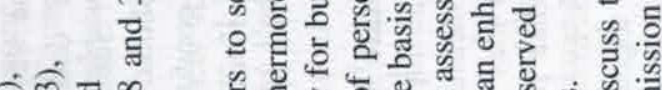

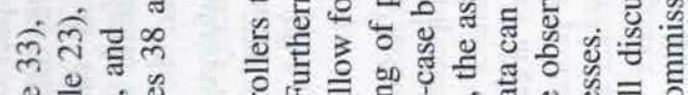

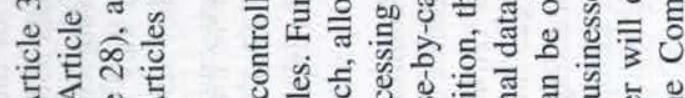

这造

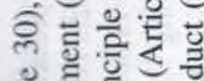

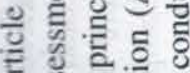

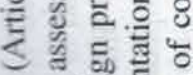

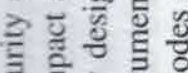

至

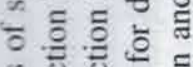

造

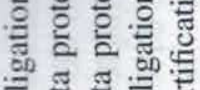

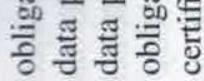

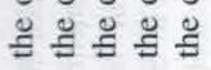

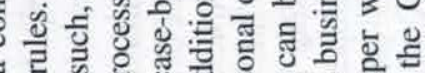

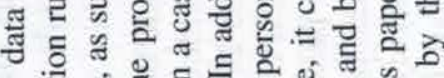

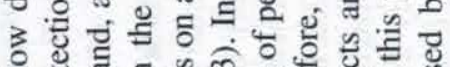

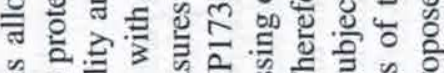

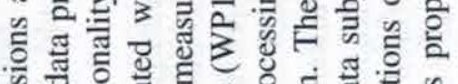

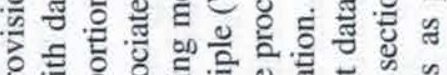

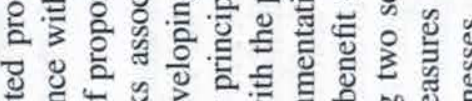

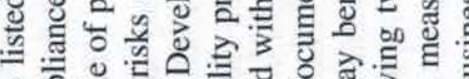

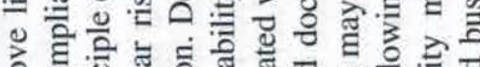

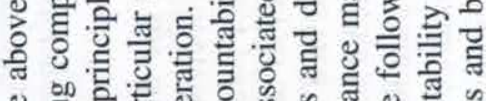

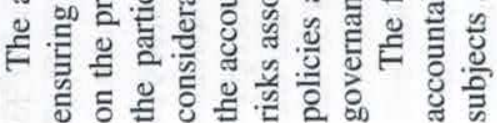

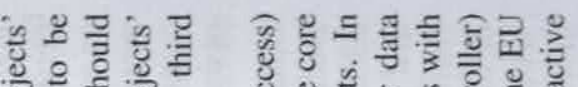

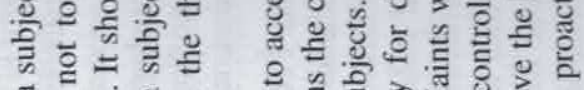

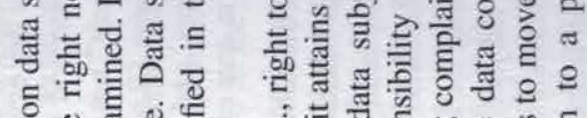

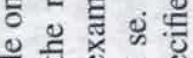

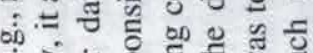

氙造

ए

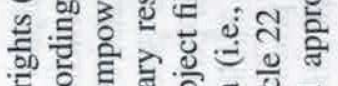

这

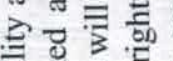

है है क्षे

ڤ

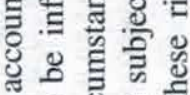

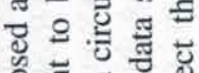

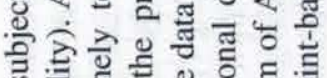

क्ञّ

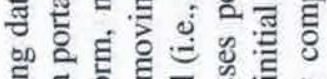

응. 햄. ⿷匚

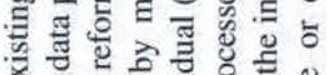

¿

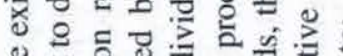

谣

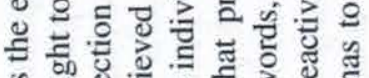

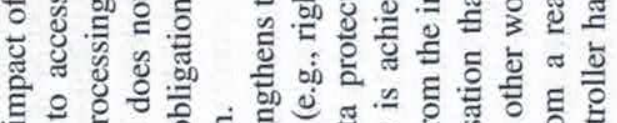

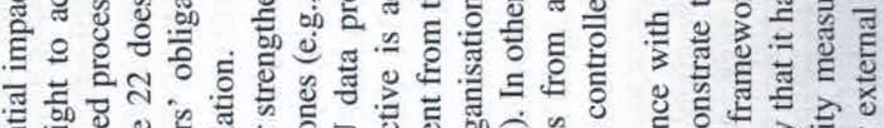

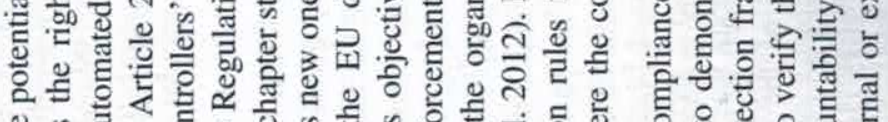

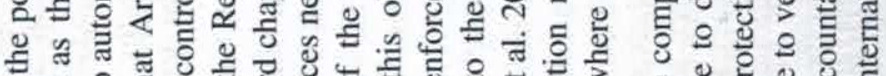

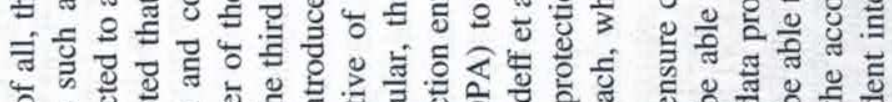
के के

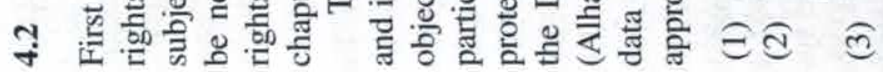

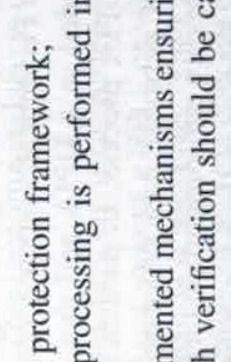

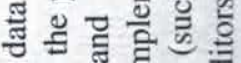
\&

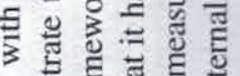
का है (2)

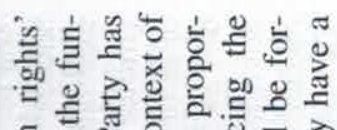

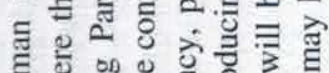

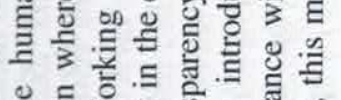

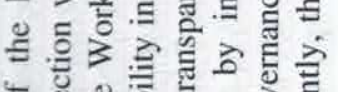

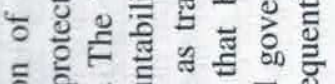
龍 ह

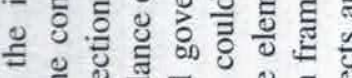
늘

플 ह5

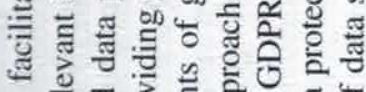

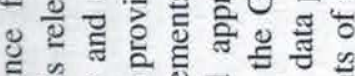

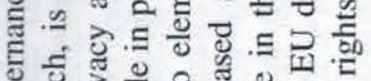

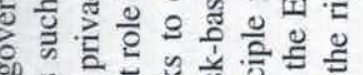

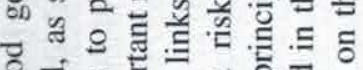

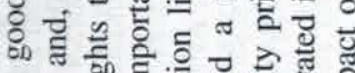

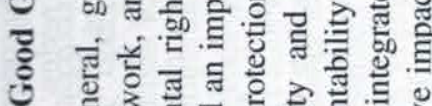

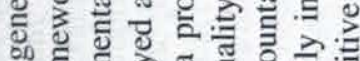

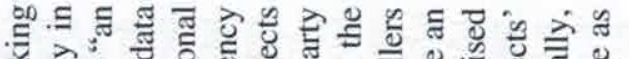

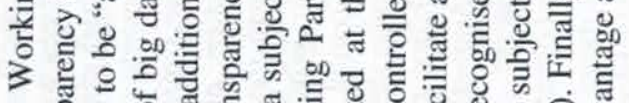

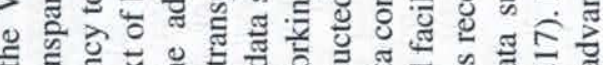

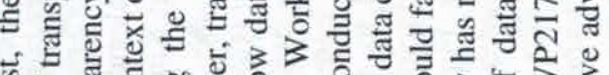

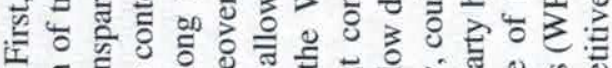

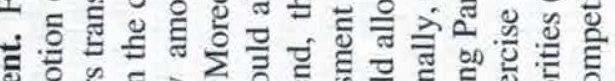

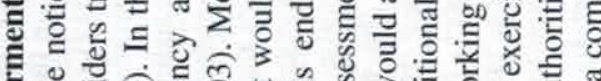

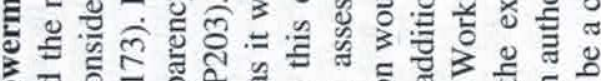

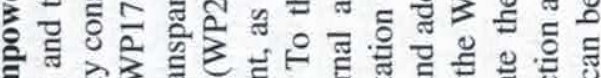

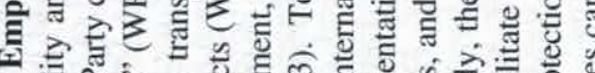
$s$ 苛

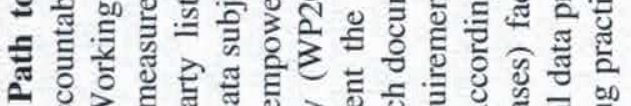

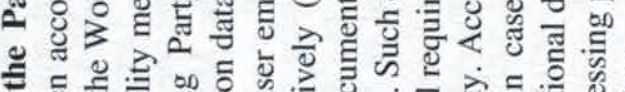
气

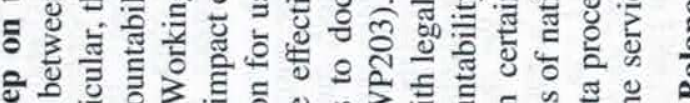

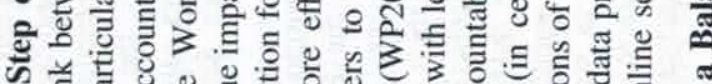

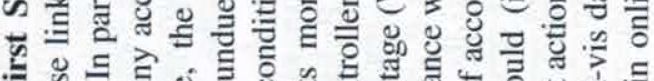

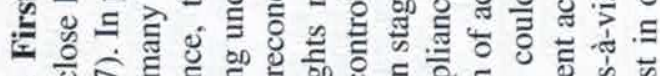

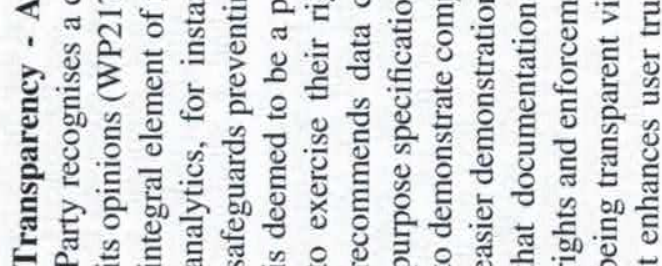

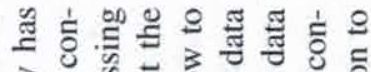

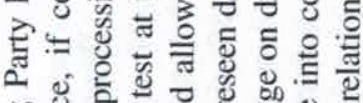

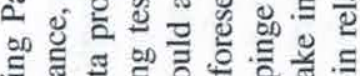

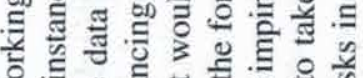

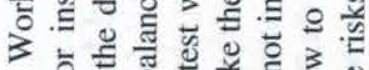

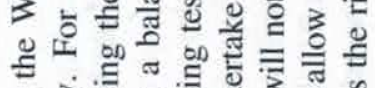

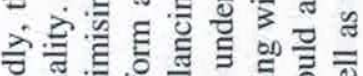

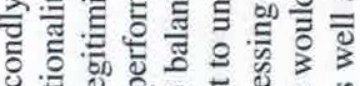
ڤ

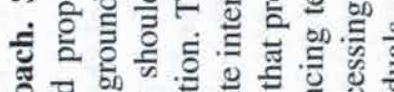

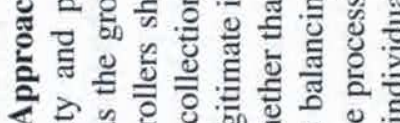

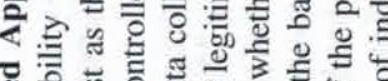

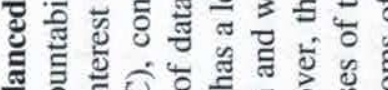

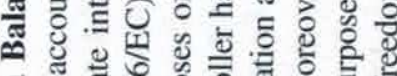

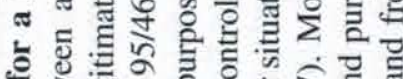

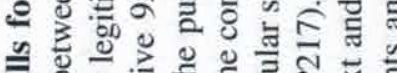

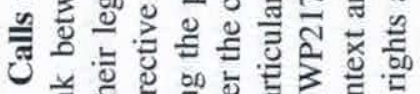

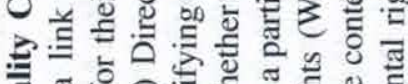
곯 गु

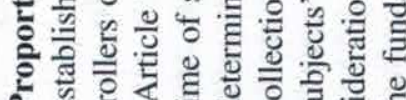

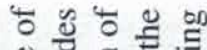

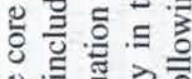
․ㅡ를

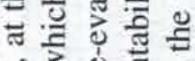

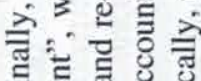
至 范宗导

s.

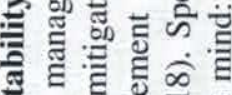
产 की

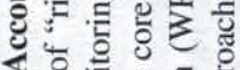
흥ㅎㅀ

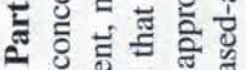
ज छ उ

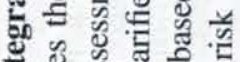
크 可 응 สี ผै

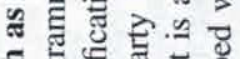
ङ ชั้ 这然客

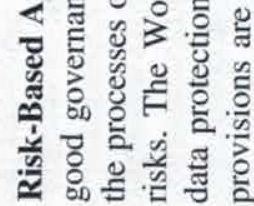


○ की 11 IU⿴囗十⺝IIII I

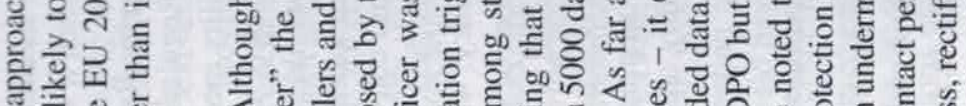
In

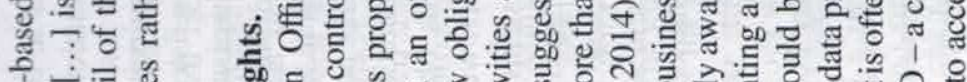

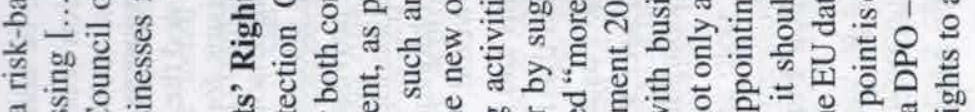
ॠ ¿

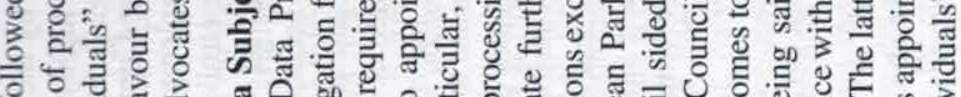
"

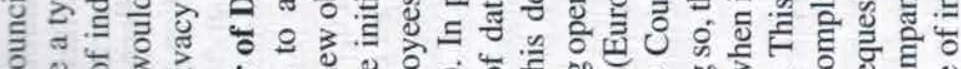
S)

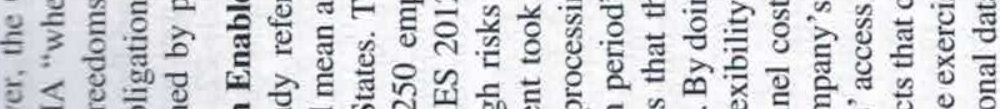

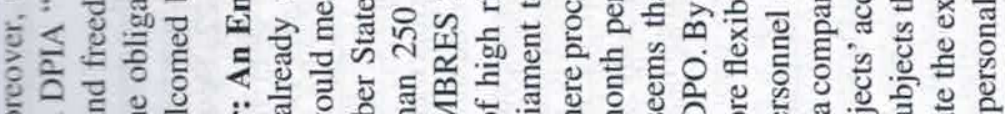

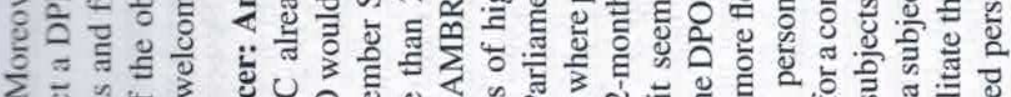

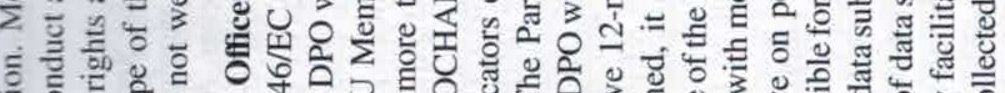

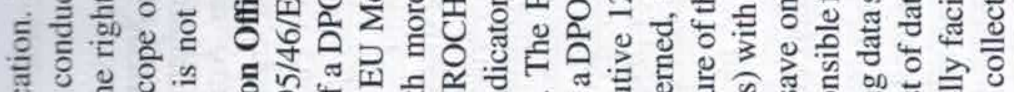
일

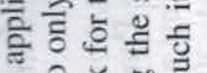

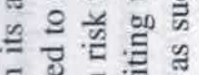

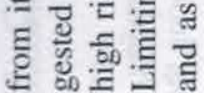

.

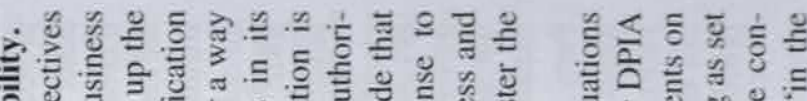

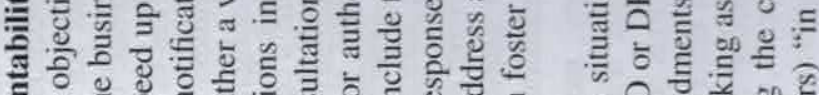

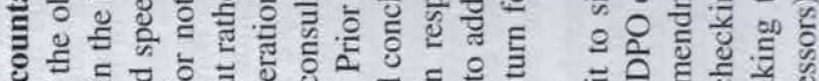

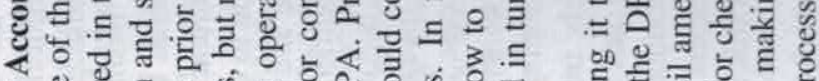

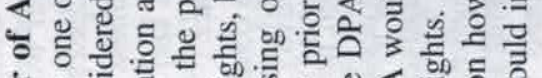

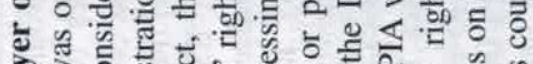
สํ. क人

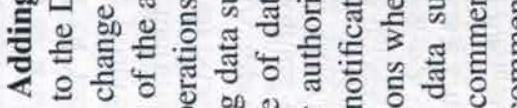

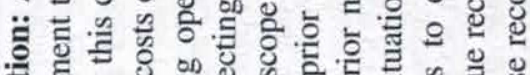

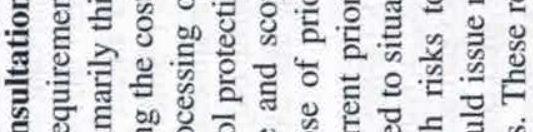

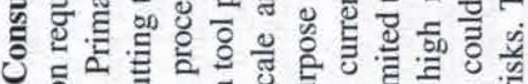

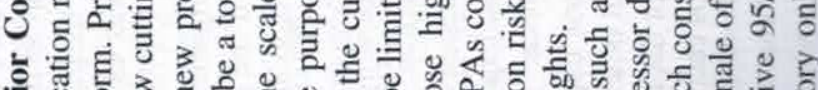

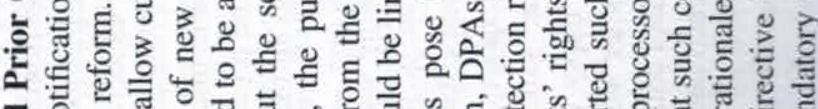

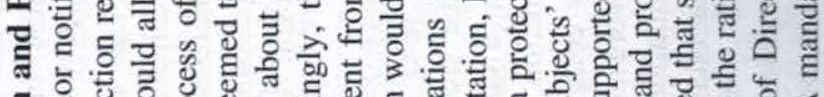

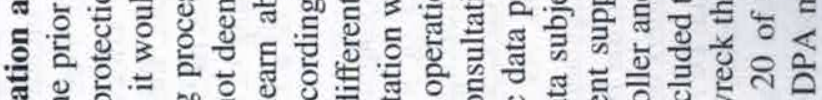
끌 은.

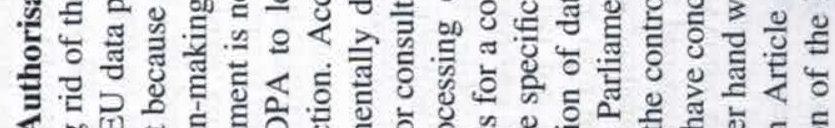

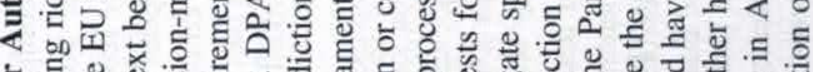

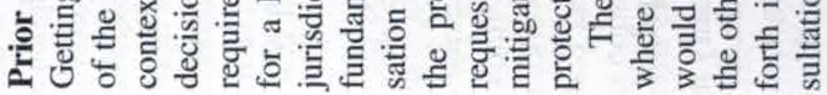

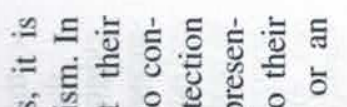
4.

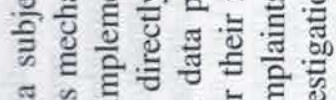
An 5

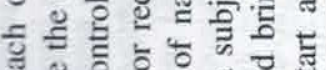

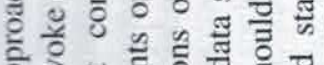

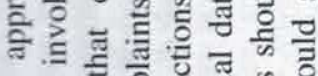

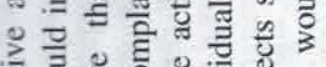
列

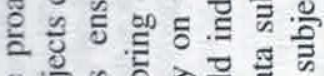

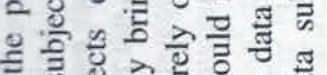
(5)

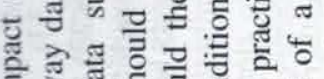

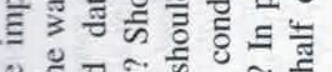

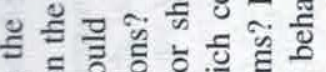
品

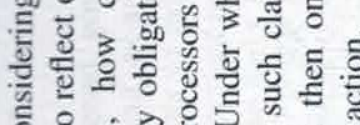

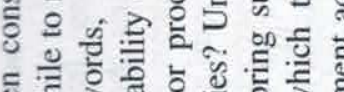

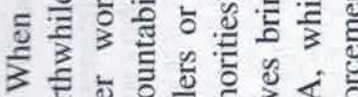

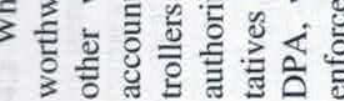

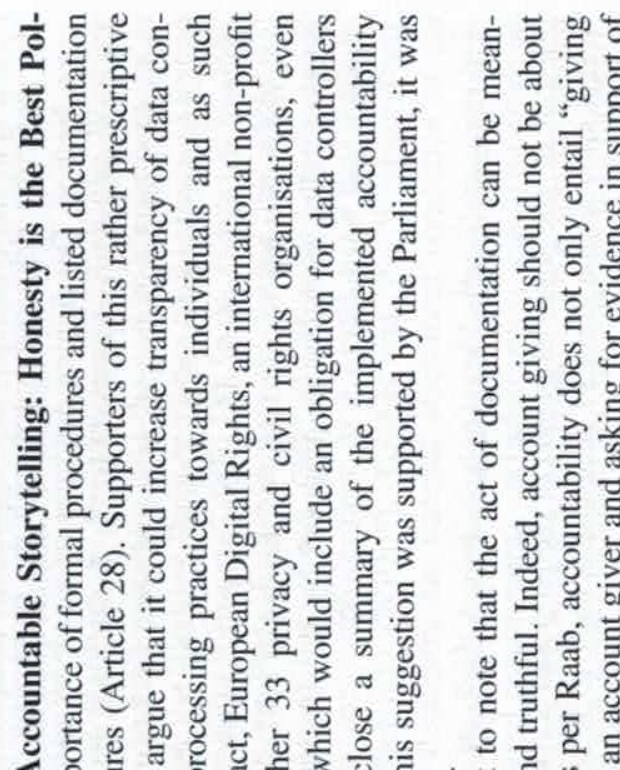

$\cong$

要

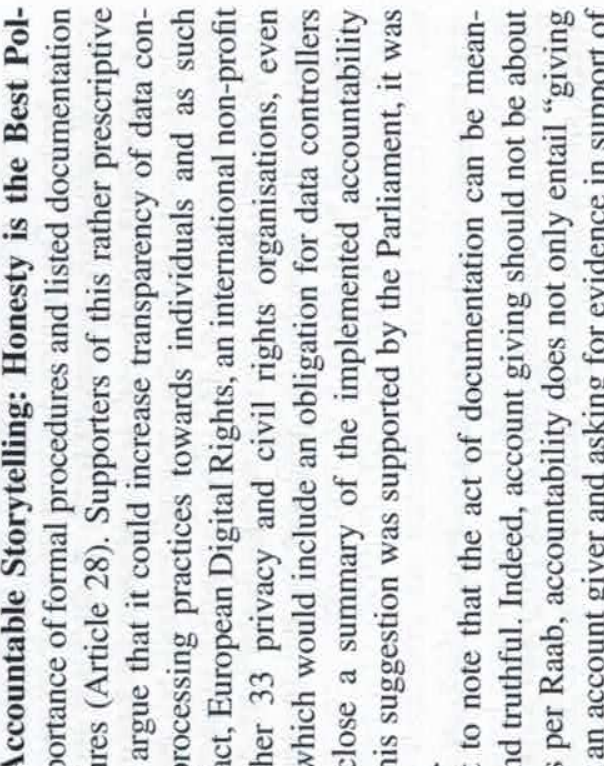

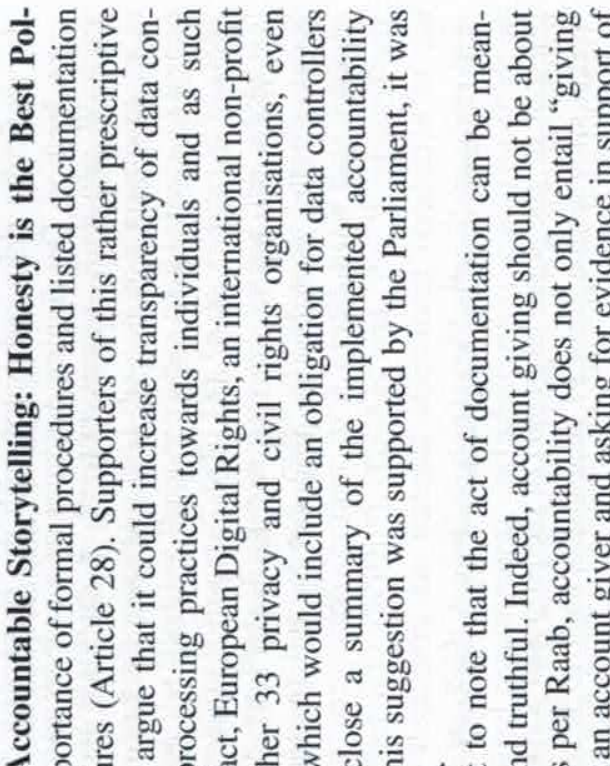

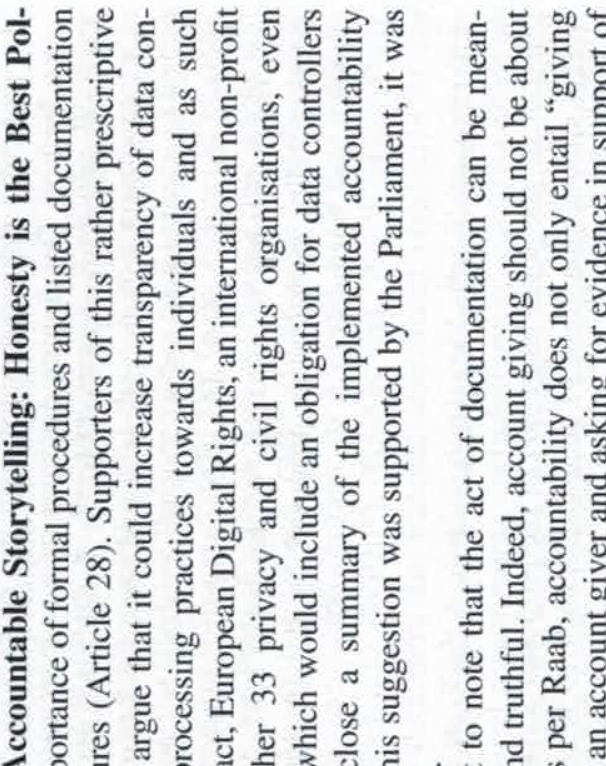

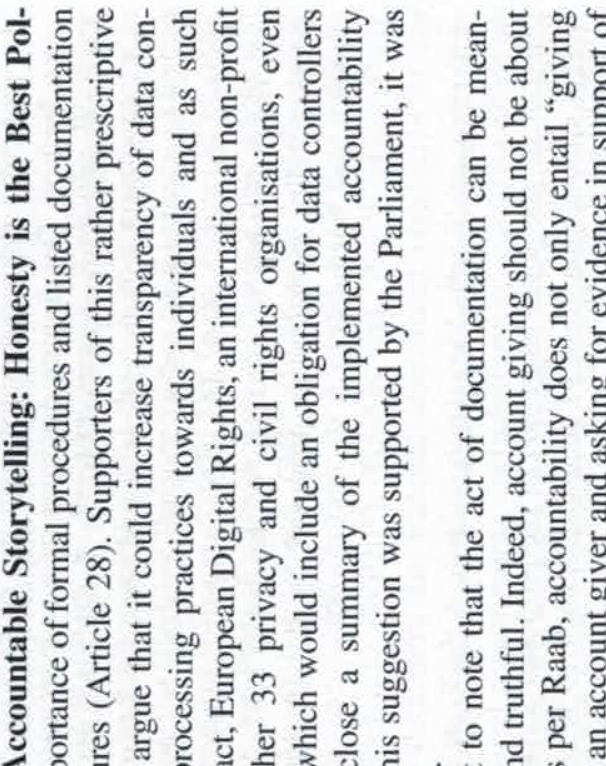

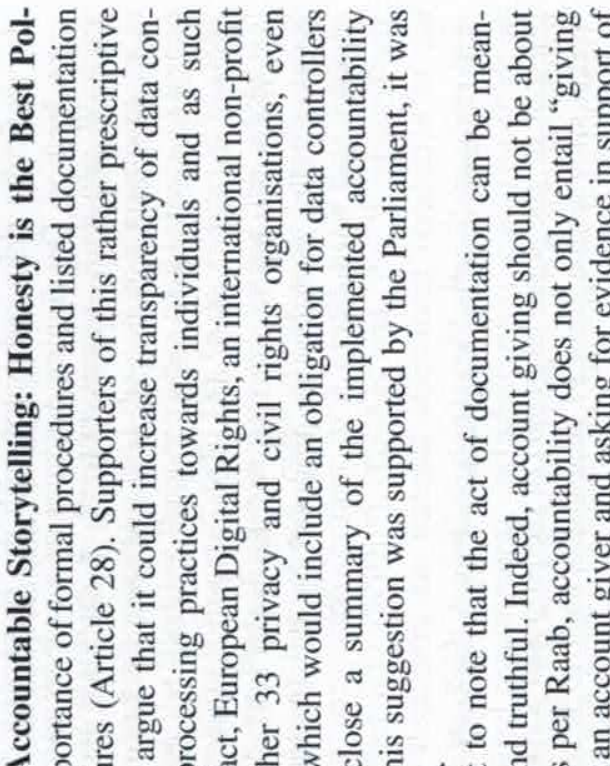

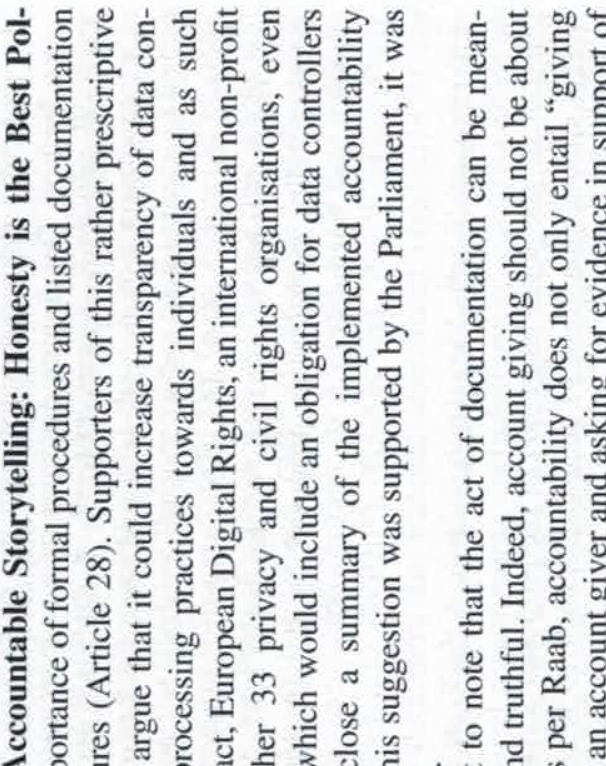

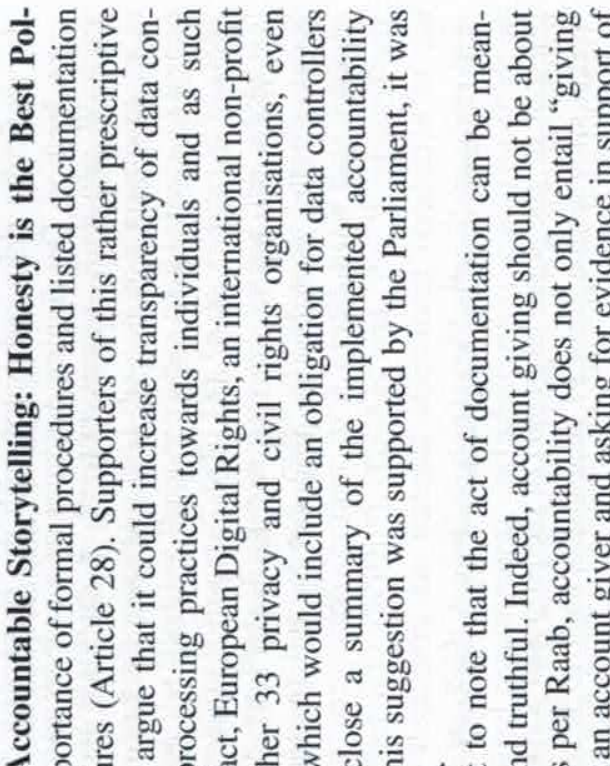

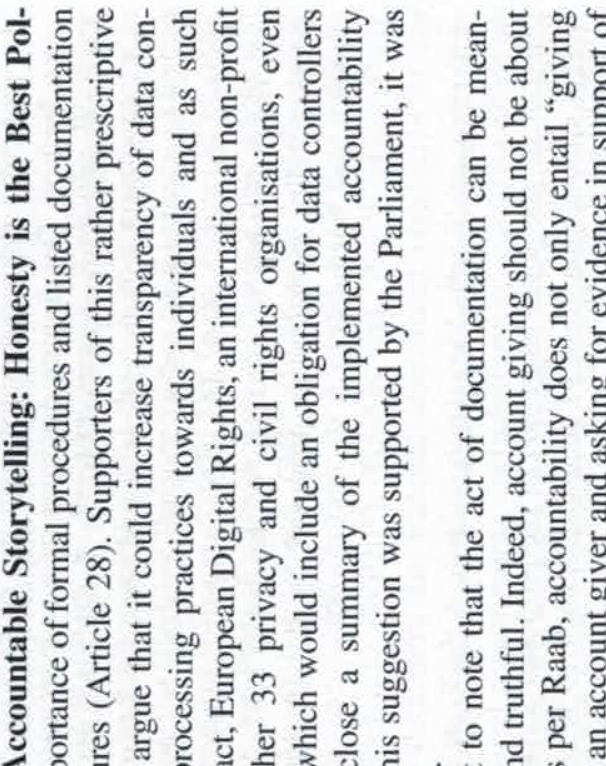

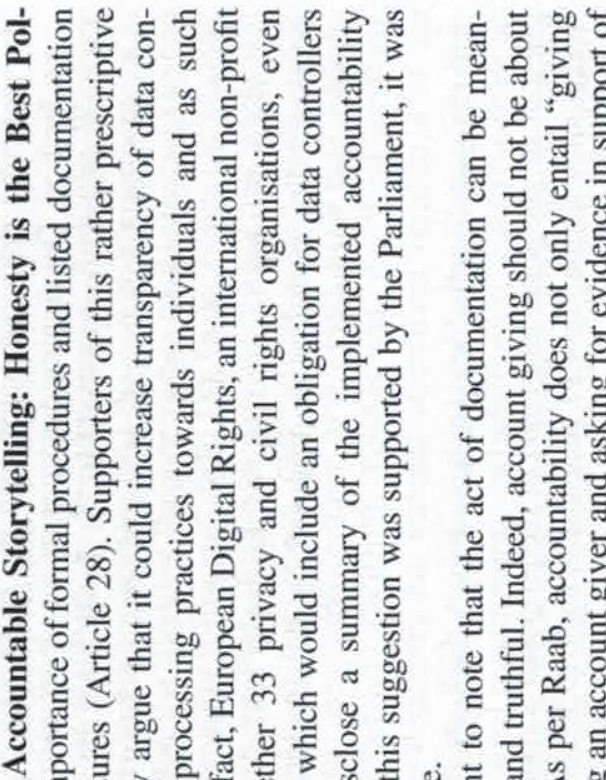

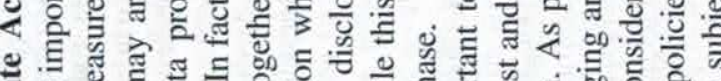

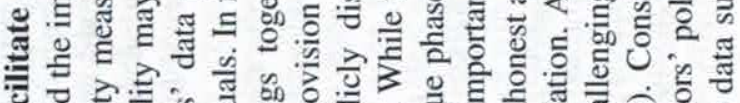

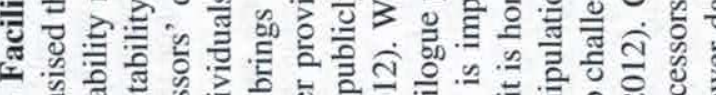
告

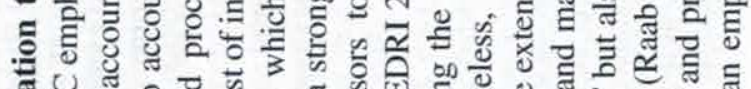
을

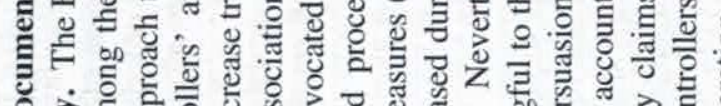

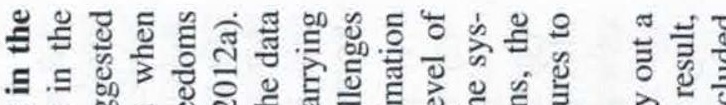

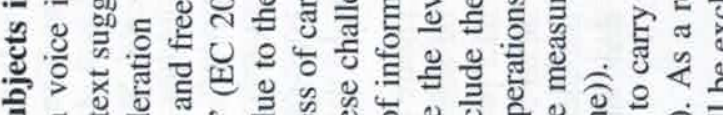

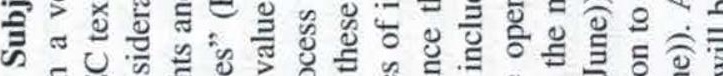

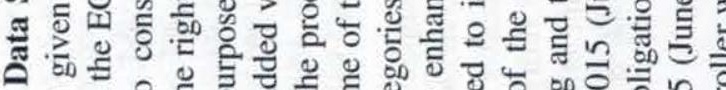
ธ。

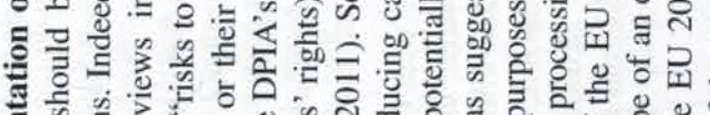

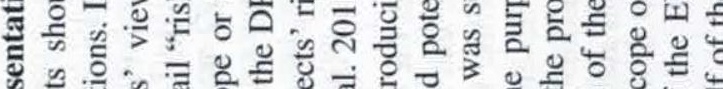

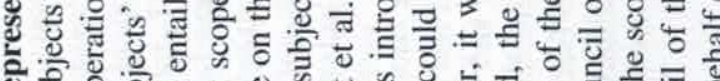

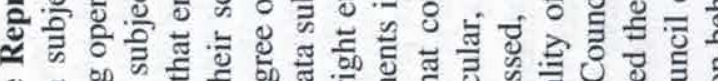

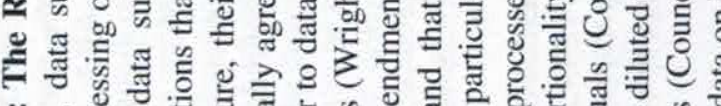

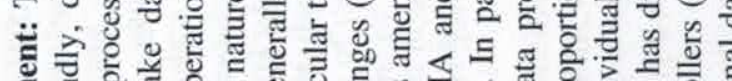

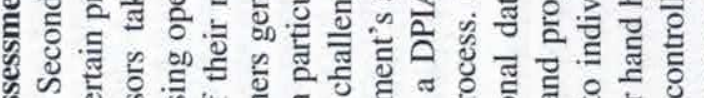

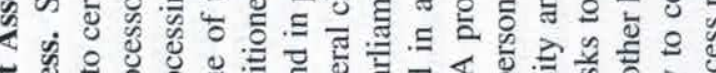

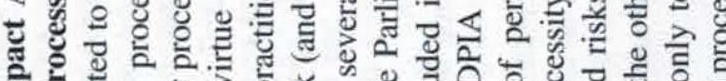

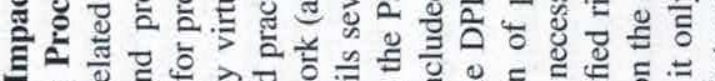
5 .

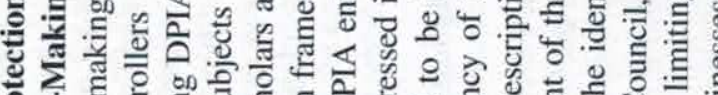

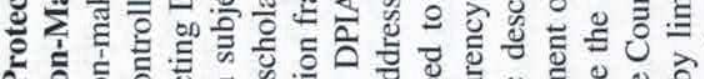
s. 

踏

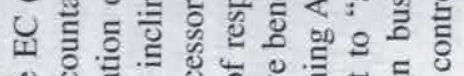

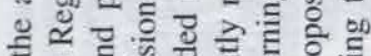
o on 5 다의

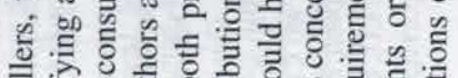

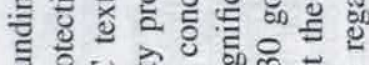

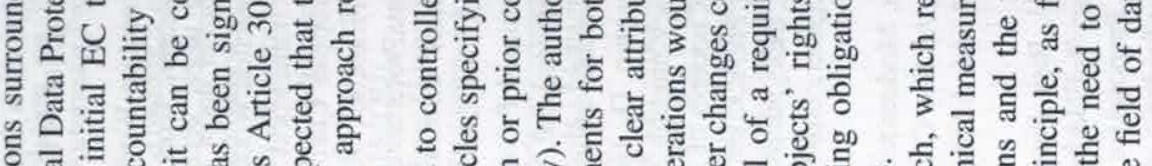

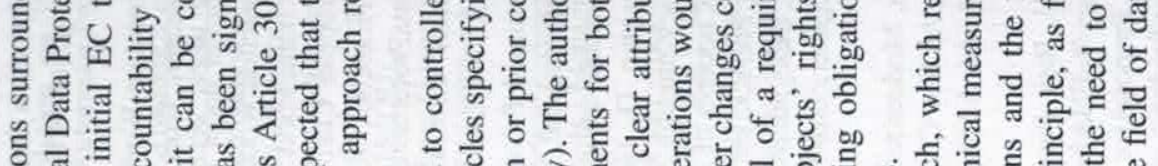

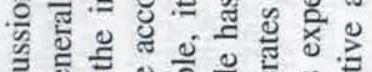

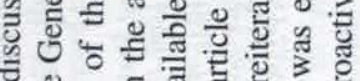

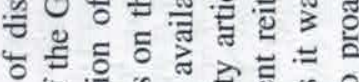
उ

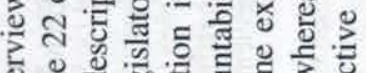

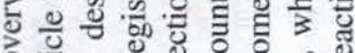

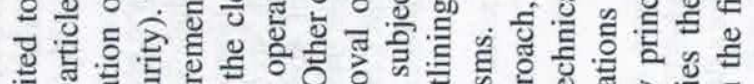

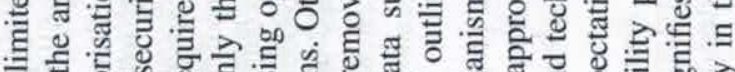

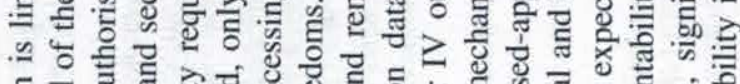
든

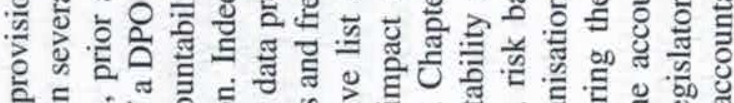
\% 든

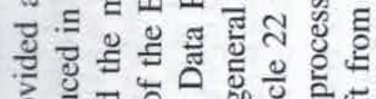

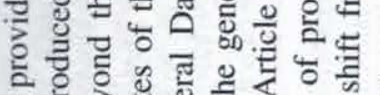

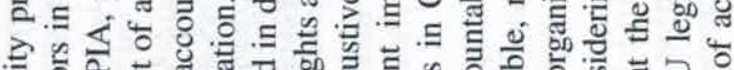

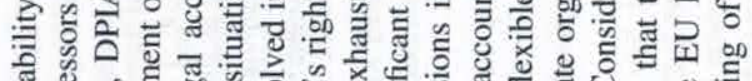

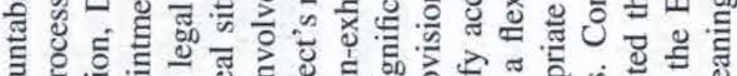

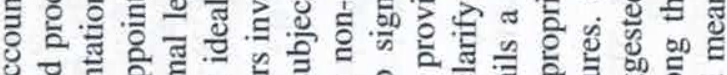

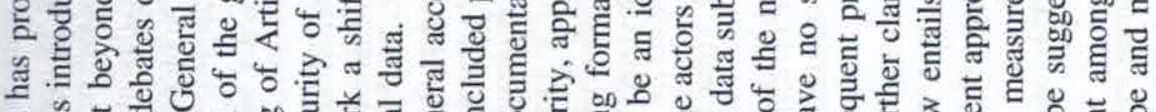

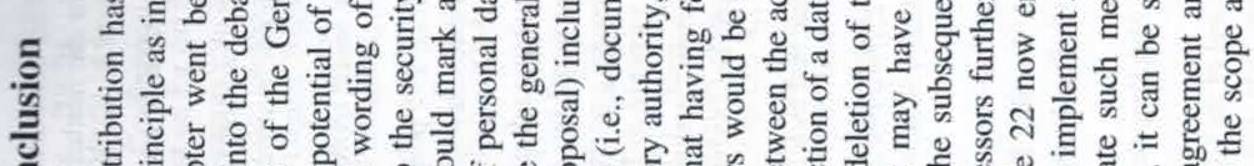
ह है

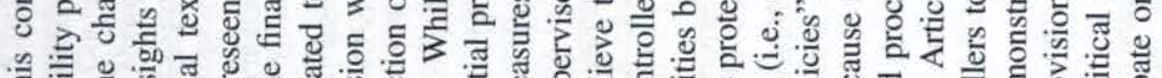

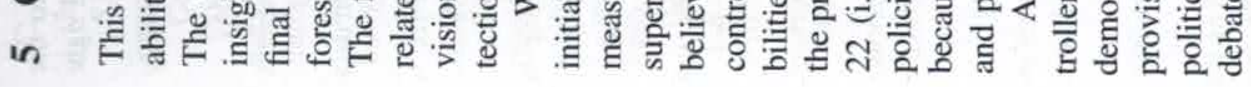

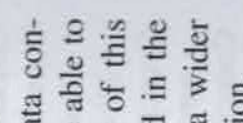

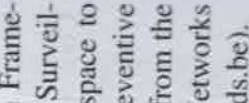

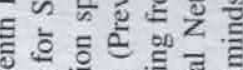

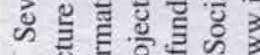

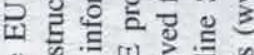

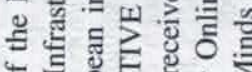

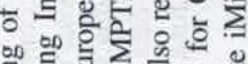

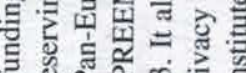

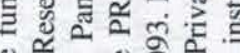

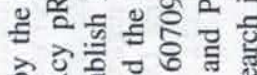

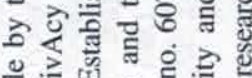

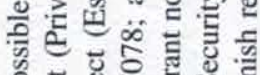

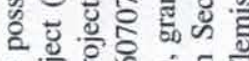
\%

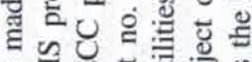

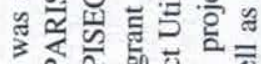

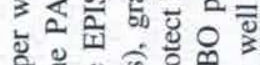

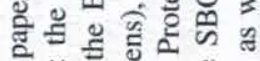

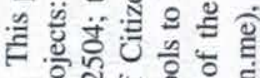

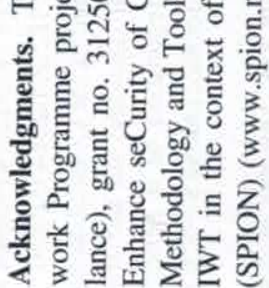

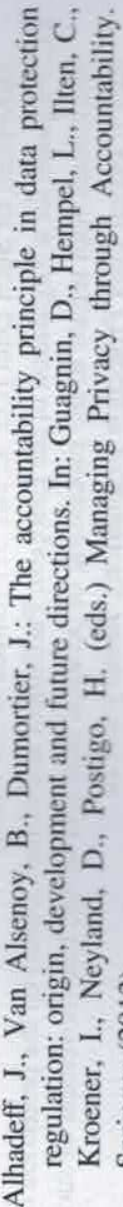

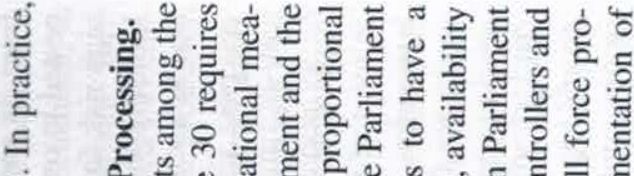

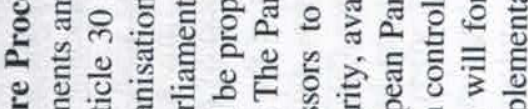

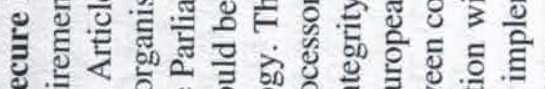

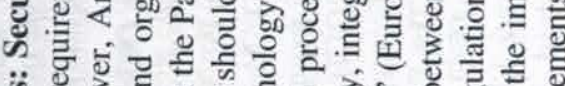

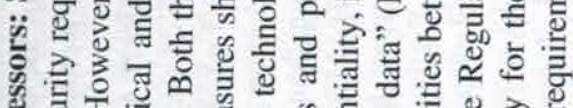

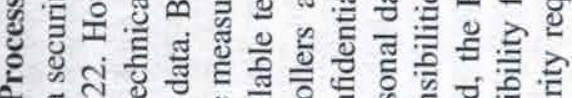

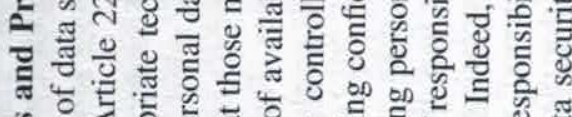 咅 숭

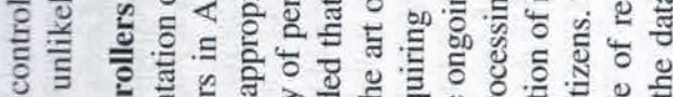 气 즐

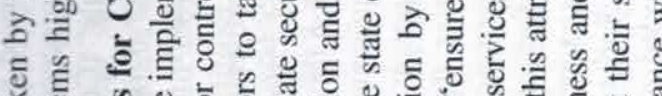

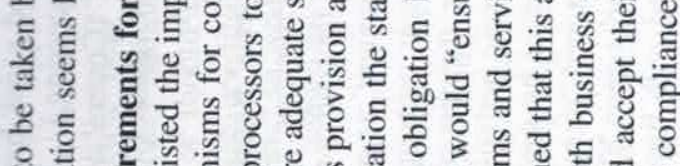 \%

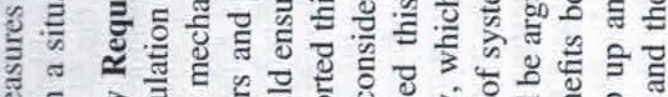

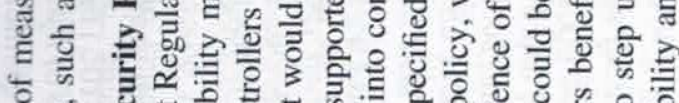

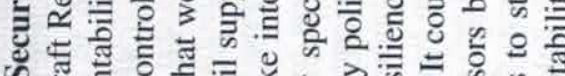

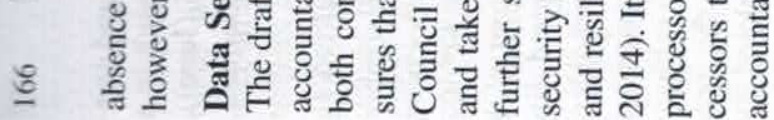

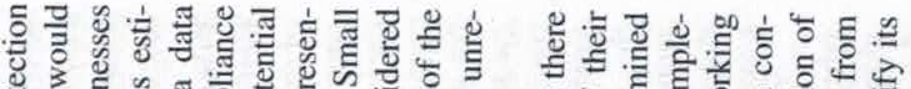

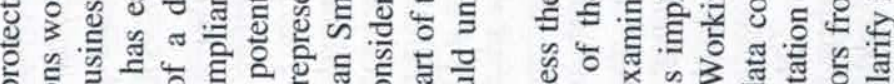

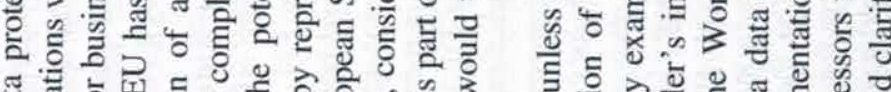

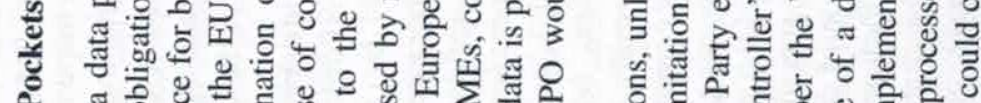
等 额

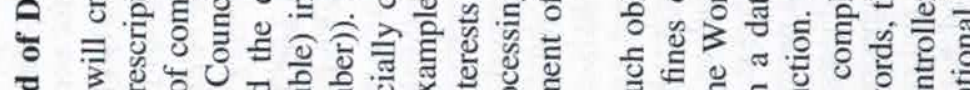

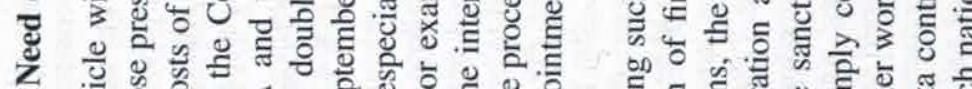

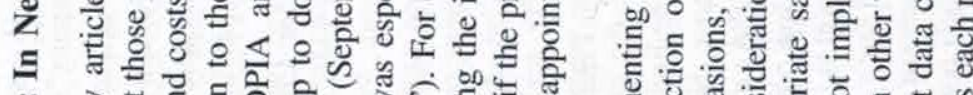

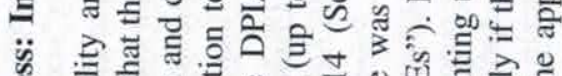
尊

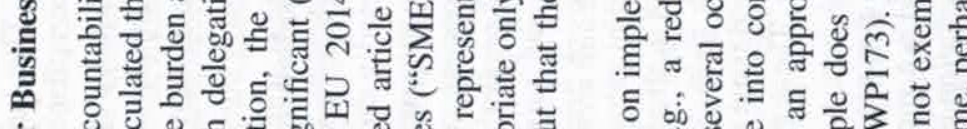
包

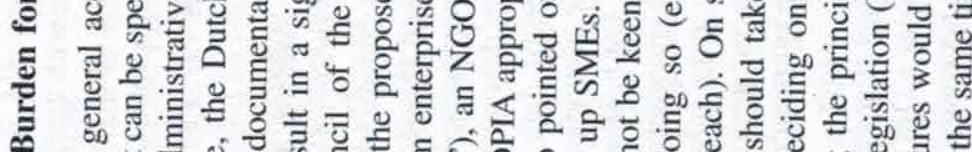

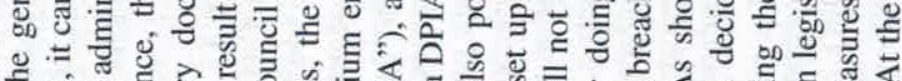

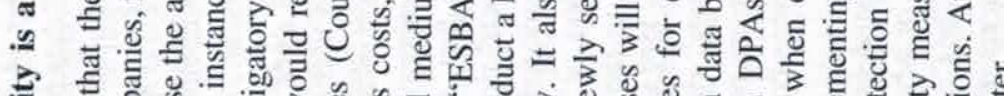

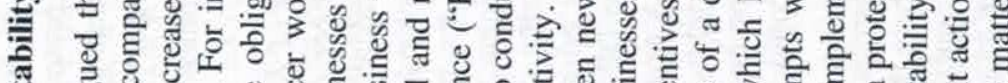

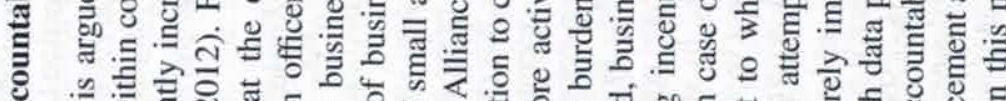

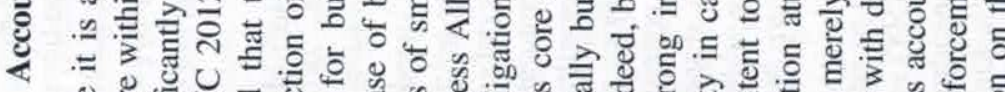

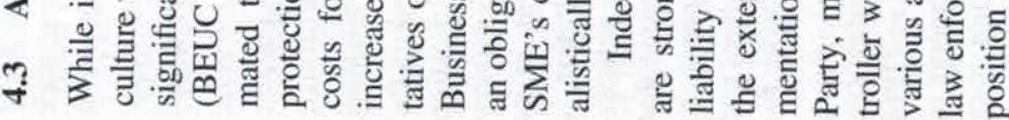




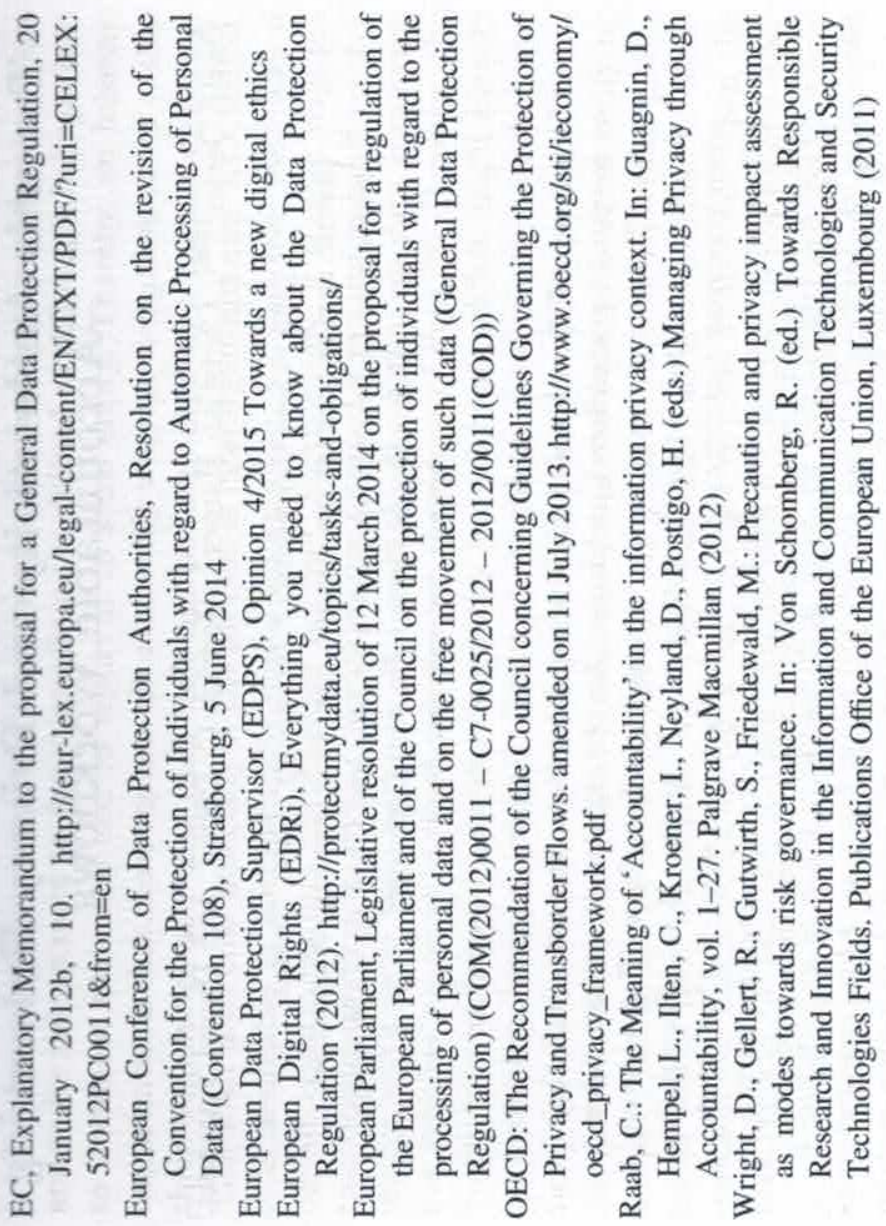

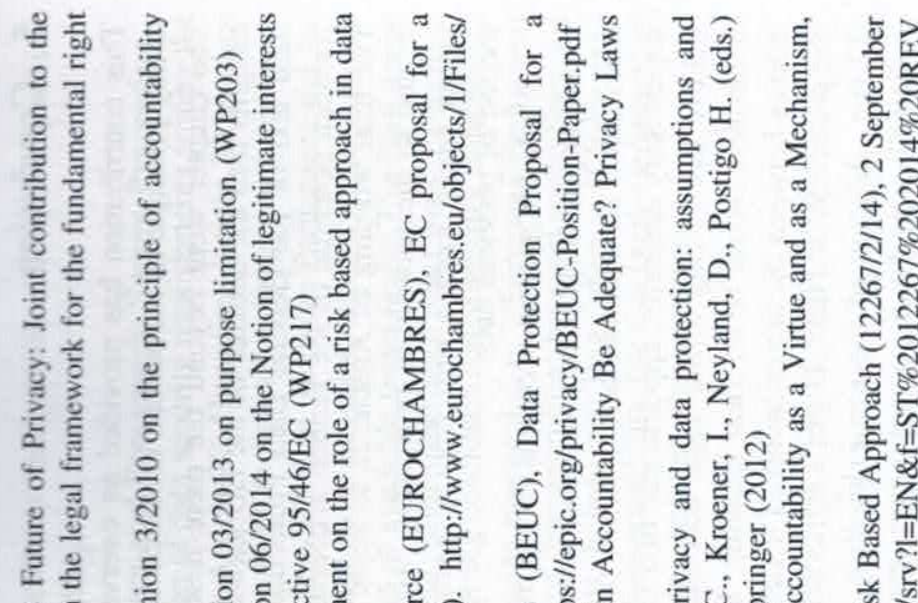

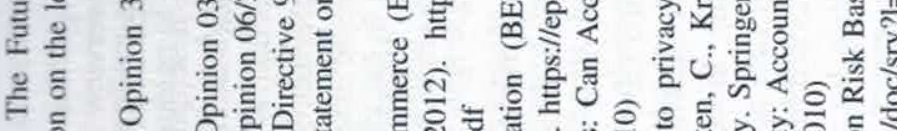

市

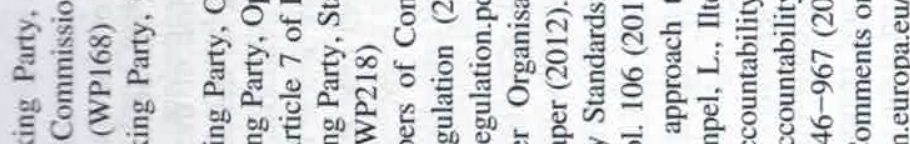

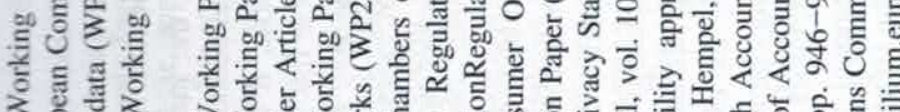

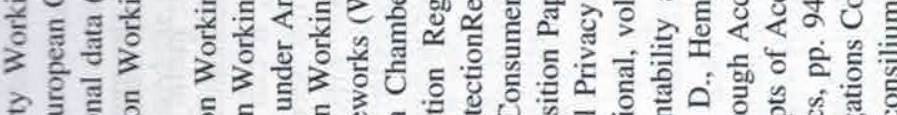

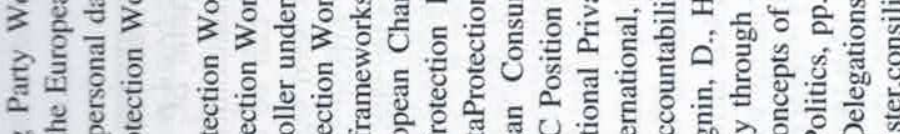

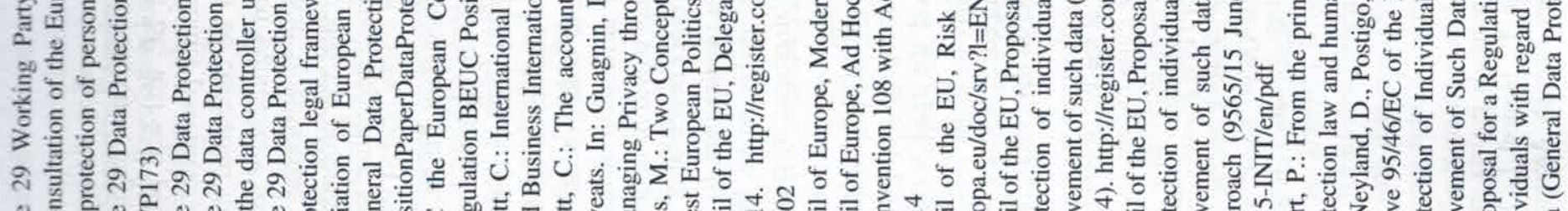

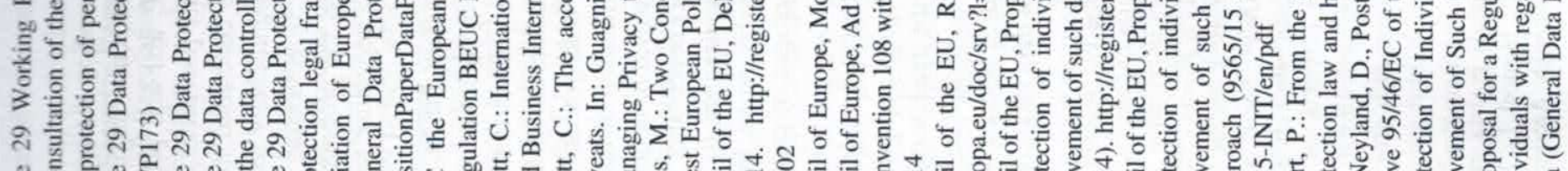

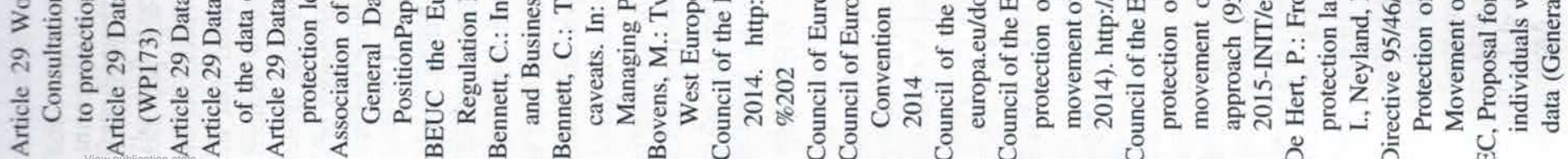

